\title{
Determinants of subnational budget/fiscal transparency: a review of empirical evidence
}

BRANKO STANIĆ, MA in Economics*

Review article**

JEL: H11, H72

https://doi.org/10.3326.pse.42.4.4

\footnotetext{
* The author would like to thank the two anonymous referees for helpful comments on the paper. This study was supported by the Croatian Science Foundation (grant number IP-2014-09-3008).

** Received: March 22, 2018

Accepted: November 9, 2018
}

\section{Branko STANIĆ}

Institute of Public Finance, Smičiklasova 21, 10000 Zagreb, Croatia

e-mail: branko.stanic@ijf.hr

ORCiD: 0000-0002-8746-6764 


\section{Abstract}

This paper provides a review of empirical research on the factors determining the budget/fiscal transparency of subnational governments. It focuses on academic online databases by conducting keyword searches that take in papers published in the period 2000-2017. Three important observations can be made: (1) there is a lack of a unique definition of budget/fiscal transparency; (2) the different definitions lead to disharmonised budget/fiscal transparency measurements; (3) there is a heterogeneity of the definition and measurement of some explanatory variables that can lead to apparent contradictions and inconsistencies in the results obtained. However, the paper provides a balanced account of core explanatory factors, emphasizing variables that, despite heterogeneity in definition and measurement, have a significant impact on the levels of subnational government budget/ fiscal transparency. Since the review involves mainly online disclosure, future studies might want to extend the observation period, or implement systematic reviews and meta-analyses to gain additional insights on this topic.

Keywords: subnational governments, budget transparency, empirical review, main determinants

\section{INTRODUCTION}

It can be said that in the past two decades, and especially in the aftermath of the financial crisis, enormous pressure has been put on governments to improve their communication with citizens by being more open, transparent and accountable. In this sense, more and more attention is being paid to fiscal and budgetary issues. Some of the most prominent initiatives that advocate for these issues are the International Budget Partnership (IBP), the Global Initiative for Fiscal Transparency (GIFT) and the Open Government Partnership (OGP). Due to the OGP's strong advocacy, a total of 75 countries have endorsed the Open Government Declaration and announced their country action plans. More recently, OGP was opened to subnational governments. In 2016, a total of 15 subnational governments signed the declaration and submitted their action plans to be implemented throughout 2017, as part of a pilot program.

Thus, the discourse of budget transparency seems to be changing, giving ever more importance to subnational governments (SNGs). Accordingly, subnational budgets are becoming a ubiquitous topic in the field of public financial management. Their importance also stems from the fact that public goods and services are particularly tangible at the subnational and especially the local level. Therefore, citizens may have more interest in participating in local budget processes, where they can see their direct impact on local development. Furthermore, subnational budget transparency enables ordinary citizens and civil society organizations to evaluate government services and facilities and suggest possible changes and needs in the future.

The internet has provided an additional incentive for proactive publishing, enabling large-scale publication of budget data, as well as constantly improving gov- 
ernment consultation processes. It can be said that the rise of the internet has furthered budget transparency by allowing rapid and inexpensive proactive disclosure (Darbishire, 2010). Consequently, SNGs have increasingly resorted to proactive budget disclosure, thus not only reducing demand-side pressures, but also changing their attitude and way of communicating with citizens. Despite the widespread availability and bidirectionality of the internet, SNG websites vary greatly in the amount of information available, comprehensiveness, timeliness and interactiveness (Caba-Pérez, Rodríguez Bolívar and López Hernández, 2008). While some SNGs run open budget policies, others oppose the practice and rarely use the low cost benefits of online proactive publishing.

The aim of this study is, hence, to review the development of research conducted previously in order to understand the factors that could influence SNG budget/ fiscal disclosure. In other words, it aims to produce a balanced account of the set of variables that significantly affect SNG budget/fiscal transparency. Some previous studies reviewed the various types of public sector disclosure (Bakar and Saleh, 2015). However, this study explores studies published in the 2000-2017 period, focusing explicitly on budget or fiscal transparency. The paper is organized as follows. Section 2 provides the methodological framework. Section 3 presents different definitions and measurements of budget/fiscal transparency. Section 4 offers a balanced account of core determinants of SNG budget/fiscal disclosure. Section 5 concludes with recommendations for future research.

\section{FRAMEWORK FOR ANALYSIS}

This review focuses on identifying explicitly quantitative studies on the determinants of SNG budget/fiscal transparency. The decision for quantitative studies is because they allow for rapid analysis and replication, which increases reliability, validity and the greater probability of obtaining unambiguous results, which contributes to better decision-making. Subnational governments include all levels below the national government, i.e. local, regional, state and provincial. To identify eligible articles, this study used the Summon discovery service - a unified search for all electronic sources of academic publications, including search interfaces such as ProQuest, EBSCO Host, Web of Science and Scopus. In addition, Google Scholar and hand searches were also used. This review includes studies published from 2000-2017, thus the focus is inherently on online disclosure. Only studies in English are taken into consideration. Search terms used were "causes of budget/ fiscal transparency", "subnational government transparency", "budget/fiscal transparency determinants", "local government transparency" or just "government transparency". Since only a few studies focused solely on budget or fiscal transparency, it should be noted that this review includes all studies that, in their transparency measure, have at least one dimension concerning the budget, i.e. revenues and expenditures. Although books were initially included in the search, no relevant sources were generated on the determinants of subnational budget/fiscal transparency. This is probably due to it being an insufficiently researched topic, which is why journals take the lead, while books are still outdated as sources of information. 
However, the eligibility criteria were designed to ensure that high-quality relevant work is included, specifically referring to empirical quantitative studies that employ budget/fiscal transparency as the dependent variable. Finally, 20 studies are included in the review. All studies are peer-reviewed and published in journals, with the exception of Ma and Wu's (2011) paper which remained as part of the $1^{\text {st }}$ Global Conference on Transparency Research held at Rutgers University.

Although it is unquestionable that every paper has made a contribution, this review highlights four papers on account of their narrow focus on budget/fiscal transparency, strong and credible evidence, and rigorous methodology used. The first is a paper by Alt, Lassen and Rose (2006), who used a unique panel data on the evolution of transparent budget procedures in the U.S. states over the past three decades. They used both case studies and quantitative analysis, presenting robust results. Serrano-Cinca, Rueda-Tomás and Portillo-Tarragona (2009) used multivariate logistic regression, focusing exclusively on the availability of budgetrelated documents. Although their results showed different levels of robustness, they proved that size of the municipality, political will, and residents' income all affect budget disclosure. Similarly, Guillamón, Bastida and Benito (2011) examined the determinants of budget and financial transparency using both OLS and 2SLS regression analysis. After controlling for endogeneity, they confirmed the robustness of the model employed. Like them, Esteller-Moré and Polo Otero (2012) remained focused on budget information disclosures. They applied their analysis to a large sample of municipalities, using a logit regression analysis for panel data, covering a seven-year period. These four papers are emphasized on the basis of measurements of the dependent variables, and the credibility and quality of the evidence and method used for determining the factors of budget/fiscal transparency. With this in mind, all the papers included in the review are presented in the following chapters, first by measuring the dependent variables and then by the established budget/fiscal transparency factors.

\section{BUDGET/FISCAL TRANSPARENCY - FROM DEFINITION TO MEASUREMENT \\ 3.1 DEFINITION}

In the literature, budget transparency and fiscal transparency are often used interchangeably, which may point to the equivalence of these two concepts. However, budget transparency is a narrower concept, focusing on the budget reports within the budget cycle. On the other hand, fiscal transparency also includes fiscal activities undertaken outside the budget sector, aiming at reducing off-budget transactions (IMF, 1997). It often includes information on all stocks as well as flows, which can hardly be found in the budget documents. Still, it is difficult to make a strict division between these two concepts, since they are intertwined and sometimes even used synonymously. Therefore, this paper will use both terms. One of the most comprehensive definitions of fiscal transparency was offered by Kopits and Craig (1998:1): 
"Fiscal transparency implies an openness toward the public at large about government structure and functions, fiscal policy intentions, public sector accounts, and projections. It involves ready access to reliable, comprehensive, timely, understandable, and internationally comparable information on government activities - whether undertaken inside or outside the government sector - so that the electorate and financial markets can accurately assess the government's financial position and the true costs and benefits of government activities, including their present and future economic and social implications".

In accordance with this definition, Alt, Lassen and Skilling (2002) stressed that financial documents should be informative and comprehensive, but at the same time easily understandable, leaving the option of independent scrutiny. In order to facilitate this inspection and monitoring of economic policies by national authorities, financial markets and international institutions, the IMF has developed a Code of Good Practices on Fiscal Transparency (IMF, 1998). The Code consisted of four main principles:

1) clarity of roles and responsibilities;

2) public availability of information;

3) open budget preparation, execution, and reporting; and

4) independent assurances of integrity.

Although this Code has helped practitioners in understanding basic concepts of fiscal transparency practices, it did not contain clear guidelines or standards that would facilitate the way and approach to measuring fiscal transparency. However, the Code was revised in 2007, pointing out that fiscal data (budget forecasts and updates, annual budget and final accounts, fiscal reports) should meet accepted data quality standards. Similarly, the OECD has developed best practices for budget transparency, although their definition of budget transparency refers to broader concept of fiscal matters: "full disclosure of all relevant fiscal information in a timely and systematic manner" (OECD, 2002:7). The best practices are divided into three parts - budget reports, specific disclosures, and integrity assurance (table 1). It is evident that only the first section corresponds to pure budget disclosure, while the other two represent wider fiscal matters. Still, the first section can be considered the first internationally recognized standard for budget reporting.

\section{TABLE 1}

The "three pillars" of the OECD's best budget transparency practices

\begin{tabular}{|c|c|c|}
\hline Budget reports & Specific disclosures & Integrity, control and accountability \\
\hline The budget & Economic assumptions & Accounting policies \\
\hline Pre-budget report & Tax expenditures & Systems and responsibility \\
\hline Monthly reports & Financial assets and liabilities & Audit \\
\hline Mid-year report & Non-financial assets & Public and parliamentary scrutiny \\
\hline Year-end report & Employee pension obligations & \\
\hline Pre-election report & Contingent liabilities & \\
\hline Long-term report & & \\
\hline
\end{tabular}


It could be said that a number of authors have defined budget/fiscal transparency not only as the availability of budget/fiscal information, but also in terms of openness and public accountability. This can best be seen in Kopits and Craig (1998) who argue that fiscal transparency does not only imply access to fiscal reports but, rather, the openness of fiscal policies and procedures. Similarly, Andreula, Chong and Guillén (2009) state that fiscal transparency, apart from open budget preparation and availability of fiscal information, also implies assurances of roles and responsibilities. In this sense, the IMF has indicated the difference between fiscal reporting and fiscal transparency. While the first refers to the production and availability of fiscal information, the second relates to the "clarity, reliability, frequency, timeliness and relevance of public fiscal reporting and the transparency of the government's fiscal policy-making process" (IMF, 2012:5).

One can conclude that there is no uniform definition of budget/fiscal transparency, which indicates a complex understanding of this topic. In other words, while there are certain standards and guidelines, different definitions and interpretations directly affect the approach and the way of measurement. Certainly, the methods and scope of measurement also depend on the context in which the research is carried out. Since this review is based on the causes rather than the effects of budget/fiscal transparency, the next section provides an empirical overview of different measurements in which the budget/fiscal transparency measure appears as a dependent variable.

\subsection{VARIOUS APPROACHES TO MEASURING SUBNATIONAL BUDGET/FISCAL TRANSPARENCY}

"Conceptually, a statistical measure of transparency is the precision of the information that is obtained, i.e. a function of its relevance and quality"

(Vishwanath and Kaufmann, 1999:4).

Given the specificities of different countries' laws, standards, procedures and contexts, one should be careful while summing, comparing and interpreting different definitions and measures of budget/fiscal transparency. In other words, subnational comparisons may be most important within, rather than across countries. Accordingly, this section seeks to present the first studies from Spain and USA since most papers on this topic are focused on the SNGs of these two countries. Then, individual studies with samples from other countries were presented.

\section{Spain}

The largest body of research comes from Spanish local governments. Gandía and Archidona (2008) presented an extensive local government online disclosure index, which consists of five sub-indices, two of which provide comprehensive budget and financial information. The other three dimensions include general government information, web presentation and navigation, and relational web to address interactivity and functionality of the web. Unlike them, Serrano-Cinca, Rueda-Tomás and Portillo-Tarragona (2009) explicitly explored budget and 
financial disclosure which they measured by sending questionnaires to municipalities regarding their online publication of nine items (based on Spanish legislation regarding local government financial disclosure), including consolidated and unconsolidated budgets, budget and annual accounts of dependent entities. Like Gandía and Archidona (2008), Caba-Pérez, Rodríguez Bolívar and López Hernández (2008) have also offered an extensive web financial disclosure index, hoping to contribute to a more harmonized framework for the structure of budget and financial information in Spanish local governments. Although the numbers of items observed are different, the main sections of their disclosure indexes are quite the same, including budget and financial information and web navigability. The main difference is that Caba-Pérez, Rodríguez Bolívar and López Hernández (2008) included non-financial information, such as indicators of economy, efficiency and effectiveness and paid more attention to the characteristics of information such as timeliness, understandability or comparability rather than content of information provided. Several authors used the government transparency measure calculated by Transparency International (TI) Spain (Guillamón, Bastida and Benito, 2011; del Sol, 2013; De Araújo and Tejedo-Romero, 2016). This index consists of five government transparency areas: (a) information about the municipal corporation; (b) social transparency; (c) financial transparency; (d) services contracting transparency; (e) urban development and procurement transparency. Among these studies, Guillamón, Bastida and Benito (2011) have contributed most to the field of budget/fiscal transparency, by focusing explicitly on TI's financial transparency section. In other words, their dependent variable was based solely on financial transparency indicators, including accounting and budget, transparency on revenues and expenditures, and information on municipal debt. Their study inspired others to use the same transparency measure for Spanish municipalities (del Sol, 2013; De Araújo and Tejedo-Romero, 2016).

A significant study was presented by Esteller-Moré and Polo Otero (2012) who employed a panel analysis by using a large sample of Catalan municipalities in the period 2001-7. They constructed their fiscal transparency index by addressing the timeliness of the mandatory disclosure of municipalities that need to submit their budget information to the Public Audit Office for Catalonia. The budget information consisted of the following: budget approval, final budget, budget balances, closed settlement budgets, treasury statement, treasury surplus, net wealth statement, income statement and indebtedness. Similarly, Caamaño-Alegre et al. (2013) have investigated Galician municipalities. They based their budget transparency measure on the IMF's revised Code of Good Practices on Fiscal Transparency and sent the questionnaires to government officials by using a Likert-type survey on open budget process, public availability of information and assurance of integrity. However, unlike Esteller-Moré and Polo Otero (2012) who offered a large number of observations and time variation, this study remained limited in this sense.

A slightly different approach to measuring government transparency was provided by Gandía, Marrahí and Huguet (2016) who looked at the presence of Web 2.0 in 
Spanish city councils. In this way, they wanted to examine the existence of participative and social web with the possibility of user-generated content. Accordingly, their disclosure index contained not only information disclosure, but also relational web. Similar to del Sol (2013), they observed the total index, as well as three subindices - ornamental index (general and citizen information), relational index, and information index, which includes budgetary and financial disclosure.

\section{United States}

Shortly after the OECD and the IMF implemented Codes of Best Practice for Fiscal Transparency, Alt, Lassen and Rose (2006) published one of the most prominent and influential studies on the causes of fiscal transparency. They examined the determinants of U.S. States both conceptually and empirically. A conceptual section included case studies of the states that managed to make significant progress towards higher transparency levels within a short time frame. On the other side, the transparency measure was not based on the availability of fiscal documents, but rather on transparency of state government budget procedures. Using the 1990s cross-sectional data from the National Association of State Budget Officers and the National Conference of State Legislatures, they extended the data to the beginnings of transparent budget procedures of US states, covering the period 1972-2002. This enabled them to use panel analysis which, to the best of my knowledge, was used for the first time in analyzing the causes of subnational fiscal transparency. Although this study offers a unique data set, comprising survey responses to a questionnaire sent to the budget officers of all fifty states, because of the period covered, it could not address e-government practices.

However, with the rapid adoption of the internet, more recent studies are mainly focused on online fiscal/budget transparency, usually examining transparency levels on governments' official websites. While Alt, Lassen and Rose (2006) offered a transparency measure with a considerable time variation, more recent studies looked at the budget/fiscal transparency at one point in time or with small time periods. Bernick et al. (2014) dropped to a lower level, exploring the fiscal transparency practices of U.S. counties in 2014. They measured the online availability of a comprehensive annual financial report (CAFR) and availability and comprehensiveness of budget information (no exact document or information is indicated). Similarly, Lowatcharin and Menifield (2015) investigated county website transparency in 2010. However, their county transparency measure (conducted by the Sunshine Review) included not only fiscal disclosure but a wider spectrum of government transparency such as permits and zoning, contracts, lobbying, etc. Relying on Groff and Pitman's (2004) description of internet financial reporting for the 100 largest U.S. municipalities, Styles and Tennyson (2007) extended the findings by examining the online availability and accessibility of CAFR data for a sample of U.S. municipalities of various sizes. 


\section{Other countries}

When it comes to pioneers in dealing with voluntary internet financial reporting in subnational governments, the paper by Laswad, Fisher and Oyelere (2005) deserves highlighting. They observed New Zealand's district, city, and regional councils, by constructing the financial transparency measure as a dichotomous variable indicating whether or not the local authority publishes financial information on the web. However, their definition of what is considered published may be somewhat confusing, since they had four disclosure categories: financial highlights only, annual reports only, annual plan only, and combinations of annual reports, plans and financial highlights together. In other words, it is not clear whether there is any council that has published, for example, both annual plan and report, in which case the analysis could change considerably. García-Tabuyo, Sáez-Martín and Caba-Pérez (2016) investigated online proactive disclosure of the 40 largest municipalities in each of the five countries of Central America - El Salvador, Nicaragua, Panama, Guatemala and Honduras. This was a valuable study, since the same transparency measure was employed for local government transparency in different country contexts. However, their measure consists of five transparency areas, where economic and financial transparency (including enacted and executed consolidated and individual budget and budget amendments) accounts for $20 \%$ the total index.

On the other hand, some studies focused explicitly on fiscal transparency, either on a sample of Brazilian states (Zuccolotto and Teixeira, 2014) or Chinese provincial government (Ma and $\mathrm{Wu}, 2011$ ). While $\mathrm{Ma}$ and $\mathrm{Wu}$ (2011) used the data collected from the first two years of the four-year survey by the Public Policy Research Center in Shanghai, Zuccolotto and Teixeira (2014) employed a fiscal transparency measure developed by Biderman and Pottomatti (2010) ${ }^{1}$. Tavares and da Cruz (2017) used TI Portugal's index of municipal transparency to assess a disclosure of Portuguese municipalities. The index is a comprehensive measure of local governemnt transparency, comprising seven dimensions one of which is economic and financial transparency. However, unlike other extensive measures, it only monitors the availability of a set of information items on a municipality's website, not taking into account accessibility, navigability, reliability or the quality of the information. A study presented by Gesuele, Metallo and Longobardi (2017) analyzed website disclosure of Italian and Spanish municipalities. Although their contribution is valuable (very few studies with an international context), they did not sufficiently address budget/fiscal transparency, except for financial statements and information about municipalities' assets, such as values, location and revenue.

\subsection{THE CHALLENGE OF SUBNATIONAL BUDGET/FISCAL TRANSPARENCY MEASUREMENT}

This review will outline several budget/fiscal transparency measurement challenges and opportunities. First, the use of the same transparency measure within a

\footnotetext{
${ }^{1}$ A study available only in Portuguese.
} 
country would allow for a comparison of the results of different studies, which could contribute to a greater understanding of inconsistent results and to the reduction or explanation of the ambiguity in the previous findings. The review shows that only a few studies used the same transparency index within a country, as with the TI Spain index used by De Araújo and Tejedo-Romero (2016), del Sol (2013), and Guillamón, Bastida and Benito (2011). Second, the transparency measure mainly involved one year of observation, and only a few studies have had a long dataset of the dependent variable, such as Alt, Lassen and Rose (2006) or Esteller-Moré and Polo Otero (2012). The longer time span of the dependent variable opens the door to many methodological approaches, enables a better quality analysis, and gives an opportunity to observe the progress of SNG budget/fiscal transparency. Third, in order to improve the observation of the causes of budget/ fiscal transparency, it is necessary to have more studies focusing solely on budgetary and fiscal indicators.

Although strong efforts have been made to standardize fiscal transparency measures at the national level, this remains an empirical and contextual challenge at the local level. However, some studies have already examined cross-country analyses by introducing their own index on a sample of municipalities (García-Tabuyo, Sáez-Martín and Caba-Pérez, 2016; Gesuele, Metallo and Longobardi, 2017). Nonetheless, to facilitate these efforts, analogously to the IBP Open Budget Survey, one of the biggest challenges (given the diversity of the local self-government system) is to create a harmonized budget/fiscal transparency index capable of being applied to the subnational governments of various countries. Results of these studies could provide more comprehensive insights into the contextual sensitivity, but also generally in examining the causes of budget/fiscal transparency.

\section{DETERMINANTS OF SUBNATIONAL BUDGET/FISCAL TRANSPARENCY - EMPIRICAL OVERVIEW}

\subsection{HETEROGENEITY OF DEFINITION AND MEASUREMENT OF VARIABLES}

This review discusses the different definitions and measurements of some variables. While different measurements are not unexpected in different countries (bearing in mind different types of data), the main issue is when these arise within a single country, which can lead to confusion and "false" variability in the results. However, when concluding and interpreting results of previous studies, attention has to be paid to the definitions and the way of measuring variables, regardless of whether they are in-country or cross-country comparisons. According to the literature, some of the most frequently used variables that can cause confusion are leverage, debt, and political competition. Although the definition of leverage is quite unambiguous, several studies have used different measures. Laswad, Fisher and Oyelere (2005) have measured it in two ways, as a ratio of long-term liabilities in total assets, and in total public equity. On the other hand, some studies have used financial expenses per capita as a proxy for leverage (Gandía and Archidona, 2008; Gandía, Marrahí and Huguet, 2016). Gandía and Archidona (2008) have equated leverage with indebtedness, making it more confusing by stating that they have 
used the cost of debt as a proxy of indebtedness, which is measured as municipal financial expenses per capita. At the same time, Caba-Pérez, Rodríguez Bolívar and López Hernández (2008) used funding costs of current year budget expenditure per capita as a proxy for the cost of debt, not assigning it to leverage, but rather to debt. Gesuele, Metallo and Longobardi (2017) have not even described their leverage measure. They defined it simply as a value of leverage per capita, while the measure was described just as natural logarithm, thus leaving it unexplained.

A unique measure for debt issuance was presented by Serrano-Cinca, Rueda-Tomás and Portillo-Tarragona (2009), who used a dichotomic variable which assigns the value of 1 if the town hall has municipal bonds in circulation, denoting a debt issuance. On the other side, some debt measures are more straight-forward, such as debt level as a percentage of the total budget (del Sol, 2013) or the often-used municipal public debt per capita (Alt, Lassen and Rose, 2006; Styles and Tennyson, 2007; Guillamón, Bastida and Benito, 2011; Caamaño-Alegre et al., 2013).

While some authors argue that a government's decision to disclose or retain information is inherently political (Wehner and de Renzio, 2013), others claim that political competition is a major driver of transparency reforms (Berliner and Erlich, 2015). However, the mode of measurement of political competition imposes the greatest variability among political determinants. There are various measures introduced for this variable. Some studies observe it as a margin of victory, measured by the difference between the percentage of votes obtained by the parties coming in first and second place (De Araújo and Tejedo-Romero, 2016, 2017; Tavares and da Cruz, 2017). Others see it as a measure of dispersion, i.e. the standard deviation of the percentage of votes received by each political party (Caba-Pérez, Rodríguez Bolívar and López Hernández, 2008; Esteller-Moré and Polo Otero, 2012). Caamaño-Alegre et al. (2013) applied the measure developed by Laakso and Taagepera (1979) - an effective number of political parties, whose calculation also contains each party's proportion of all votes. Several studies focused explicitly on competition in the municipal council. Laswad, Fisher and Oyelere (2005), and Serrano-Cinca, Rueda-Tomás and Portillo-Tarragona (2009) measured almost the same thing. While the first used the ratio of candidates to council positions available, the latter defined it as the ratio of candidates to councillors elected. However, despite the different definitions, it could be said that their measure is the same, since it seldom happens that available council positions are not filled.

By using different measures for one variable, results may vary within one study, let alone comparing different studies, contexts or subnational international comparisons. In this sense, one should be careful while summing and interpreting results because the measure always speaks more than the variable name.

\subsection{MAIN DETERMINANTS}

In order to provide the centrality of each variable in the literature, table 2 presents the most frequently used explanatory variables. It shows how many studies that 
are included in the review used a particular independent variable. The complete classification and measurements of variables can be seen in the appendix.

TABle 2

Most frequently used explanatory variables

Financial

\begin{tabular}{c}
$\mathbf{\%}$ \\
\hline 40 \\
\hline 35 \\
\hline 35 \\
\hline 20 \\
\hline 15 \\
\hline 10
\end{tabular}

Debt

Government's wealth 55

Political competition

$\begin{array}{r}\hline 55 \\ \hline 55 \\ \hline 45 \\ \hline 35 \\ \hline 20 \\ \hline 15\end{array}$

Political ideology

Voter turnout

Executive features

E-government achievements

Citizens and the media

Population size/density 60

Citizens' characteristics (education, age, gender) 45

Citizens' wealth

Internet access 35

Unemployment 30

Media use and visibility

25

Source: Author.

However, this overview aims to analyze the most frequently used variables that have shown a significant influence, with particular emphasis on those that, despite heterogeneity in definition and measurement, show a significant effect. In this way, the review strives to produce a balanced account of core variables that greatly affect the level of subnational fiscal/budget transparency (table 3). To produce this account, the rule is that only variables that were used in at least two papers and which show a significant result in more than $50 \%$ of cases were included. Accordingly, three basic variable categories are distinguished: financial, political, and citizens and the media. The following section reveals these variables and focuses on the explanation of the results obtained, based on some underpinnings in previous studies.

\subsubsection{FINANCIAL VARIABLES}

Financial leverage and debt levels are the most important financial factors determining subnational budget/fiscal transparency. Leverage refers to the use of borrowed funds to finance public activities. In this sense, it can represent the amount of debt of the government, showing the close relation of these two terms. According to Zimmerman (1977), governments want to reduce the cost of debt by increas- 
ing resources available for other activities that are more efficient in increasing government's welfare than the payment of high interest rates. Accordingly, politicians are encouraged to publish government information, which in turn facilitates monitoring by creditors. This can be achieved easily and at low-cost by online proactive reporting, which is confirmed in several studies, even if they have different leverage measurements (Laswad, Fisher and Oyelere, 2005; Gandía, Marrahí and Huguet, 2016; Gesuele, Metallo and Longobardi, 2017).

\section{TABLE 3}

\section{Main determinants of subnational budget/fiscal transparency}

\begin{tabular}{|c|c|c|}
\hline Category & Variable & Different measurements \\
\hline \multirow{6}{*}{ Financial } & \multirow{3}{*}{ Leverage } & Ratio of long-term liabilities to total assets \\
\hline & & Ratio of long-term liabilities to total public equity \\
\hline & & Total executed expenses per capita \\
\hline & \multirow{3}{*}{ Debt } & Percentage of debt in total budget \\
\hline & & Public debt per capita \\
\hline & & $\begin{array}{l}\text { Funding costs of the current year budget expenditure } \\
\text { per capita }\end{array}$ \\
\hline \multirow{10}{*}{ Political } & \multirow{5}{*}{$\begin{array}{l}\text { Political } \\
\text { competition }\end{array}$} & $\begin{array}{l}\text { Divided government; gubernatorial competition; } \\
\text { legislative competition }\end{array}$ \\
\hline & & $\begin{array}{l}1 \text { if city council is governed by one of the majority } \\
\text { political parties in the country }\end{array}$ \\
\hline & & $\begin{array}{l}\text { Measure of dispersion, i.e. the standard deviation of the } \\
\text { percentage of votes received by each political party }\end{array}$ \\
\hline & & Effective number of political parties \\
\hline & & $\begin{array}{l}\text { Margin of victory, measured by the difference between } \\
\text { the percentage of votes obtained by the parties coming } \\
\text { in first and second place }\end{array}$ \\
\hline & \multirow{2}{*}{$\begin{array}{l}\text { Executive } \\
\text { features }\end{array}$} & Mayor's gender \\
\hline & & Number of incumbent's consecutive terms (tenure) \\
\hline & \multirow{3}{*}{$\begin{array}{l}\text { Governance } \\
\text { type }\end{array}$} & 1 if district councils, 0 regional or city councils \\
\hline & & 1 if provincial capitals \\
\hline & & $\begin{array}{l}\text { Form of government ( } 1 \text { if council-manager, } 0 \\
\text { commission and council-elected executive) }\end{array}$ \\
\hline \multirow{9}{*}{$\begin{array}{l}\text { Citizens and } \\
\text { the media }\end{array}$} & \multirow{2}{*}{ Population } & Number of inhabitants \\
\hline & & Population density \\
\hline & \multirow{3}{*}{ Internet access } & Percentage of households with home internet access \\
\hline & & $\begin{array}{l}\text { Fixed internet access connections over } 200 \text { kilobits per } \\
\text { second in at least one direction per } 1,000 \text { households }\end{array}$ \\
\hline & & Internet penetration \\
\hline & Unemployment & Unemployment rate \\
\hline & \multirow{3}{*}{ Media } & $\begin{array}{l}\text { Intensity of use of social media, measured by the } \\
\text { number of tweets }\end{array}$ \\
\hline & & Press visibility \\
\hline & & Internet visibility \\
\hline
\end{tabular}

Source: Author. 
Moreover, politicians are incentivized to reduce debt levels because it allows for lower property taxes that will increase their probability of re-election (Gore, Sachs and Trzcinka, 2004). In this way, incumbents are encouraged to use internet reporting and disclose more information as this helps lenders to regularly monitor governments activities (Debreceny, Gray and Rahman, 2002). In other words, the greater the dependence on external funding sources the greater the disclosure (Ingram, 1984). Severel studies have confirmed this, finding a positive relationship between debt levels and budget/fiscal reporting (Styles and Tennyson, 2007; Caba-Pérez, Rodríguez Bolívar and López Hernández, 2008; Caamaño-Alegre et al., 2013; De Araújo and Tejedo-Romero, 2017). However, Alt, Lassen and Rose (2006) found a negative association, concluding that higher debt reduces fiscal transparency. But it should be pointed out that they employed debt variable only as a control variable. Finally, given the different leverage and debt measures used, the significance of these variables in determining fiscal/budgetary transparency is even greater.

\subsubsection{POLITICAL VARIABLES Political competition}

When it comes to political determinants, there are three variables that contribute to explaining different levels of subnational budget/fiscal transparency - political competition, different executive features, and type of government. Stronger political competition encourages incumbents to bear higher monitoring costs, because if they do not keep pre-election promises, they are exposed to the long-term costs of re-election failure (Evans and Patton, 1987). Esteller-Moré and Polo Otero (2012) stressed the importance of political competition in times in which an incumbent's re-election is uncertain. With a strong competition, agents use fiscal disclosure as their strategic instrument to have a greater chance of being reelected. However, when it comes to the degree of fiscal information they wish to provide, agents face a trade-off. According to Ferejohn (1986) higher levels of fiscal transparency allow politicians to have higher wages, since principals are now ready to pay more taxes. At the same time, greater information disclosure diverts agents from rent extraction. Accordingly, in the cases of strong competition, higher transparency becomes agents' instrument only if a trade-off is solved in favour of higher salaries. In cases of low competition, transparency becomes less important for politicians, as they in this case have high expectations of staying in power (Piotrowski and Bertelli, 2010).

It is argued that parties in power have greater benefits from divulging information in both a low and a high political competition environment. In the case of high competition, they have the incentive to show their current actions and good management (Caba Pérez, Rodríguez Bolívar and López Hernández, 2014), while low competition makes them more confident of their position in power and so willing to reveal more information (Grimmelikhuijsen and Welch, 2012). By contrast, other competing parties in a high competition environment abstain from the risk of disclosure, as this may reduce their ability to control their message (Caba Pérez, Rodríguez Bolívar and López Hernández, 2014). 
In this context, the empirical results on political competition are mixed. While several authors proved that competition fosters subnational fiscal transparency (Caamaño-Alegre et al., 2013; Gandía and Archidona, 2008; Tavares and da Cruz, 2017), others disputed this, showing a negative correlation (Alt, Lassen and Rose, 2006; De Araújo and Tejedo-Romero, 2016; Gandía, Marrahí and Huguet, 2016). Generally, it is hard to report the true effect of political competition, since the context, data used, and different country characteristics may greatly affect this variability in the results. However, even with wide range of measurements used, political competition proved to be a significant predictor of subnational fiscal transparency.

\section{Executive features}

Different incumbent characteristics and features also affect government's decision on divulging or withholding fiscal information. The mayor's gender is the first of those features, showing a significant influence on subnational transparency levels. Many studies have investigated the differences between women and men officials, mostly favouring women's leadership style and its effect on decision-making in the public sector. It is argued that female mayors are more likely than their male counterparts to actively engage citizens in the decision-making, thus fostering participation, communication and different inputs (Fox and Schuhmann, 1999). Some studies are concerned with gender and ethics, suggesting that women are less likely to behave unethically in the workplace in order to achieve greater financial rewards (Bernardi and Arnold, 1997; Krishnan and Parsons, 2008). In addition, female mayors may be less likely to experience the principal-agent dilemma, since they are more ethically minded than men (Khazanchi, 1995). Some authors stress that the critical representation of women in governance structures can affect the way of government functioning, making it more socially responsive and transparent (Rodríguez-Garcia, 2015). Several authors have empirically confirmed these underpinnings, finding a positive relationship between a female mayor and budget transparency (De Araújo and Tejedo-Romero, 2017; Tavares and da Cruz, 2017). However, Gesuele, Metallo and Longobardi (2017) proved the opposite, but showing the significance in only one of the three models presented.

It is also argued that longer tenure in office reduces pressure on the officials to disclose information. Tavares and da Cruz (2017) found that the number of an incumbent's consecutive terms in office is one of the factors most detrimental to transparency. This is consistent with the findings by Berliner (2014), who claimed that turnover in executive office fosters the adoption of freedom of information laws, which are associated with increased transparency. By contrast, $\mathrm{Ma}$ and $\mathrm{Wu}$ (2011) showed a positive correlation, stressing that governments need more time to achieve the support needed for the implementation of administrative reforms so as to foster transparency and openness. It could also be argued, however, that much more research is needed, as only few studies have employed this variable, thus limiting a better insight into the true effects of this variable. 


\section{Governance type}

There has been a tendency for researchers to include a dummy variable that addresses the type or form of the government, thus pointing to the governance structure. This could be an important argument, especially in the context of implementation of the new public management (NPM). Namely, within this approach, citizens are viewed as customers and public servants as public managers, while transparency and accountability are perceived as fundamental elements of good governance (Caba Pérez, Rodríguez Bolívar and López Hernández, 2008). Laswad, Fisher and Oyelere (2005) were among the first to use the variable "form of local authority" by distinguishing between district, city and regional councils. They found that regional and city councils are more transparent than district councils. However, it is not clear why they have not used a nominal variable, rather than a dichotomous, to address all three council types separately. It should be noted, though, that the governance type may vary greatly among countries, thus depending on the setting of the public administration of a country. In some cases, the central government has administration delegations across the country, which are assigned to the several subnational units. In Spain, for example, these are provincial capitals where the central government holds offices to provide efficiently and effectively some additional services to citizens. These political capitals proved to be less transparent than other Spanish cities (del Sol, 2013). Since this is a specific country context, it would be difficult to find theoretical underpinnings that support this evidence. In spite of that, the author indicated that the reason for low transparency could be the capitals' privileged treatment by the central government. Lowatcharin and Menifield (2015) on a sample of US counties found that council-manager governments tend to be more transparent than their mayor-council counterparts. It could be argued, however, that council-managers are more prone to the adoption of web technologies and e-government solutions, rather than mere transparency (Moon, 2002). In other words, higher transparency in these governments is not a goal by itself, but comes as a result of their propensity for web technology implementations.

\subsubsection{CITIZENS AND THE MEDIA}

\section{Population}

One of the variables most often used in explaining SNG fiscal transparency is the number of inhabitants. It is widely discussed that larger SNGs have the extra resources and capacities to adopt technical and managerial innovations faster (Smith and Taebel, 1985; Norris and Kraemer, 1996). This is explained by the greater pressure they face in finding different ways for a better supply of public services. In addition, they may have a better trained stuff, a larger budget, and an established IT department, which helps them to embrace e-government practices (Moon and Norris, 2005). These underpinnings were strongly confirmed by several authors (del Sol, 2013; Guillamón, Bastida and Benito, 2011; Lowatcharin and Menifield, 2015; Serrano-Cinca, Rueda-Tomás and Portillo-Tarragona, 2009). However, a study presented by Esteller-Moré and Polo Otero (2012) has revealed new insights into the population variable. Given the heterogeneity of the sample 
with a wide range of population size, they split the sample into a large and small population. They found a negative relationship in the small sample, but a positive in the larger sample (for the very big municipalities), pointing to a non-linear relationship between the number of inhabitants and fiscal transparency. They stressed that unlike small municipalities, very large units have greater capacity to fulfil their legal obligations, which could more than compensate for their potential propensity to be less transparent.

\section{Internet access}

According to Debreceny, Gray and Rahman (2002), the rise in the use of the internet has brought different views to fiscal transparency. From the user's perspective, it is recognized as a facilitator in the demand for fiscal transparency, while from the supplier's perspective it is perceived as a tool for more effective dissemination of information. Internet take-up has affected the behaviour of governments, which are now divulging additional information and services online. Thus, its rise has brought about an improved transparency and financial accountability, reducing the costs of dissemination (Pina, Torres and Royo, 2010). Several studies that investigated online (mainly website) transparency reported that greater and better internet access in the SNGs positively affects their fiscal transparency (CabaPérez, Rodríguez Bolívar and López Hernández, 2008; Gandía and Archidona, 2008; De Araújo and Tejedo-Romero, 2017). García-Tabuyo, Sáez-Martín and Caba-Pérez (2016) found a positive association with mandatory disclosure, but surprisingly, the relationship with voluntary reporting proved to be negative. Although the argument may be somewhat shallow, they explained this by saying that voluntary information disclosure could be larger in municipalities with higher internet penetration and political commitment because by increasing the transparency levels, politicians aim to attract the votes of inactive citizens.

\section{Unemployment}

It has been argued that lower economic development and associated higher unemployment rates are damaging to civic engagement, i.e. the demand for greater opportunities to participate in the decision-making is lessened. Some studies used unemployment as a proxy for SNG economic status and found that higher economic status (lower unemployment) positively affects transparency in public administration (Piotrowski and van Ryzin, 2007). In accordance with these underpinnings, the results largely indicate that higher unemployment rates are detrimental to fiscal transparency (Caamaño-Alegre et al., 2013; De Araújo and Tejedo-Romero, 2016; del Sol, 2013; Tavares and da Cruz, 2017).

\section{Media}

Various authors have stressed the importance of public media visibility in a government's divulging of information (Zimmerman, 1977; Ingram, 1984; Laswad, Fisher and Oyelere, 2005). It is argued that greater visibility and frequency of press reporting on a government's activities and work contributes to resolving the principalagent dilemma by reducing information asymmetries between citizens and author- 
ities. However, it should be noted that the media, citizens and politicians often have different interests. In this context, public media may be more interested in publishing exclusive information, such as corruption scandals. This, in turn, affects the government's behavior, for it will limit the disclosure of information so as to avoid them being "misused" in the media (Laswad, Fisher and Oyelere, 2005; García and García-García, 2010; Cuadrado-Ballesteros et al., 2017). Nevertheless, studies have found that press and public media visibility as well as frequency of social media usage by SNGs have a positive impact on their fiscal transparency (Laswad, Fisher and Oyelere, 2005; Gandía and Archidona, 2008; Gandía, Marrahí and Huguet, 2016; Gesuele, Metallo and Longobardi, 2017).

\section{DISCUSSION AND CONCLUSION}

This paper has provided a review of empirical studies on the determinants of subnational government's budget/fiscal transparency in the period 2000-2017. Several important observations should be emphasized. First, in order to determine the factors involved, it is necessary to have a clear definition of budget/fiscal transparency. However, there is no consensus about this. Moreover, different definitions are interwoven, leading to budgetary and fiscal transparency being used interchangeably. The lack of a clear definition conduces to an inadequate measurement of budget transparency, which can significantly affect the credibility of the results of such research. Thus, instead of having effective transparency, this lack of clarity leads to opaque, fuzzy, or zombie transparency (Fox, 2007; Michener, 2015), where there is a lack of disaggregation or better descriptive details. Without parameters, as Michener (2015) stressed, the quality and comparability of transparency is compromised. Secondly, different approaches to measuring budget transparency, especially within the same country, reduce the effective comparison potential and lead to ambiguity. Thirdly, heterogeneity of the definition and measurement of explanatory variables can lead to apparent contradiction and inconsistency of the obtained results.

In this paper three basic categories that determine subnational government budget/ fiscal transparency are established: (1) financial (leverage and debt), (2) political (political competition, executive features and governance type), and (3) citizens and the media (population, internet access, unemployment, and the media). This conclusion is based on the review of 20 selected papers, following the abovementioned methodology. Looking at the wider literature, some of the findings can be related to findings at the national level, where the main factors of fiscal transparency are political, namely political (electoral) competition, and the level of governmental democracy (Hollyer, Rosendorff and Vreeland, 2011; Wehner and de Renzio, 2013). Although citizens and the media, and financial factors determine SNG fiscal transparency, at the national level its effect seems negligible. This may be due to the reduced participation opportunities and pressures of citizens on the national government, or different structures and sources of funding of national and SNGs. Moreover, Wehner and de Renzio (2013) have concluded that external initiatives might not play a great role in strenghtening fiscal accountabil- 
ity at the national level when the internal demand (citizens, media) is weak. However, when it comes to a wider literature on other types of public sector transparency, all findings are highly correlated (Bakar and Saleh, 2015), including all three established categories.

A vast majority of studies tend to focus on local governments, thus neglecting other types of public sector organizations such as federal and state governments, or quasi-government bodies. Very few studies involved different countries in an investigation of subnational international comparisons. In this sense, the challenge would be to create a harmonized budget transparency measure that could be applied to subnational governments of different countries. Further such research could offer a more comprehensive insight into the factors implicated in budget/ fiscal transparency, including different country characteristics and contexts. Furthermore, greater consistency in selecting proxy measures for certain variables could contribute to a clearer interpretation of results, while the greater time span of budget transparency data would allow for richer methodology solutions and observations.

Like any other studies, this study has a few limitations. It does not take into account research before 2000, as the focus is rather on online disclosure. Future studies may extend observation time. Furthermore, no meta-analytic studies were included. However, this paper can serve as the basis and motivation for implementing systematic reviews and meta-analyses on this topic. In spite of these limitations, it is believed that the study may provide rich insights for both interested researchers and practitioners.

\section{Disclosure statement}

The author does not have any conflict of interest. 
468
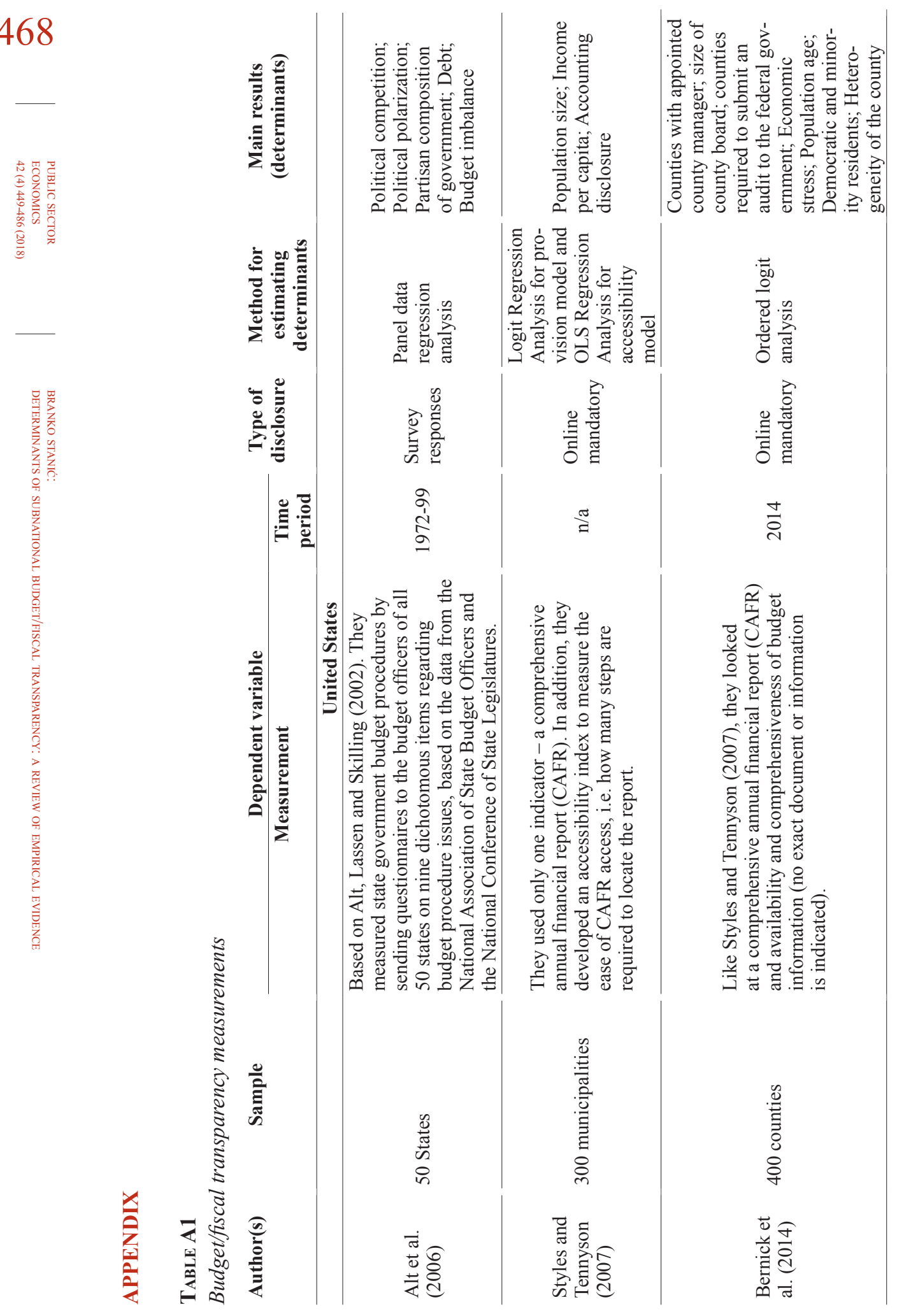

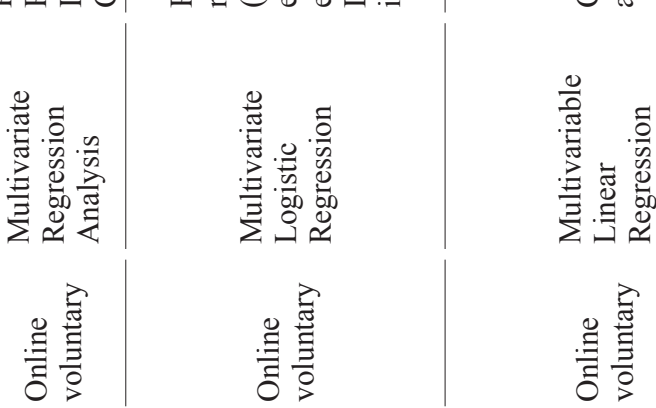

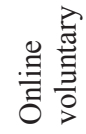

¿্ণ

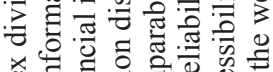

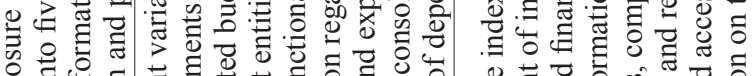

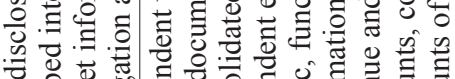

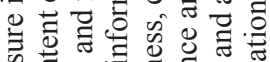

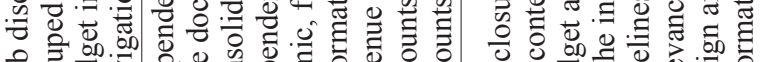

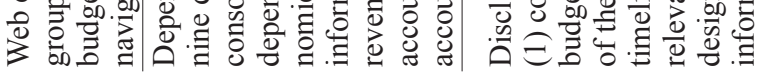
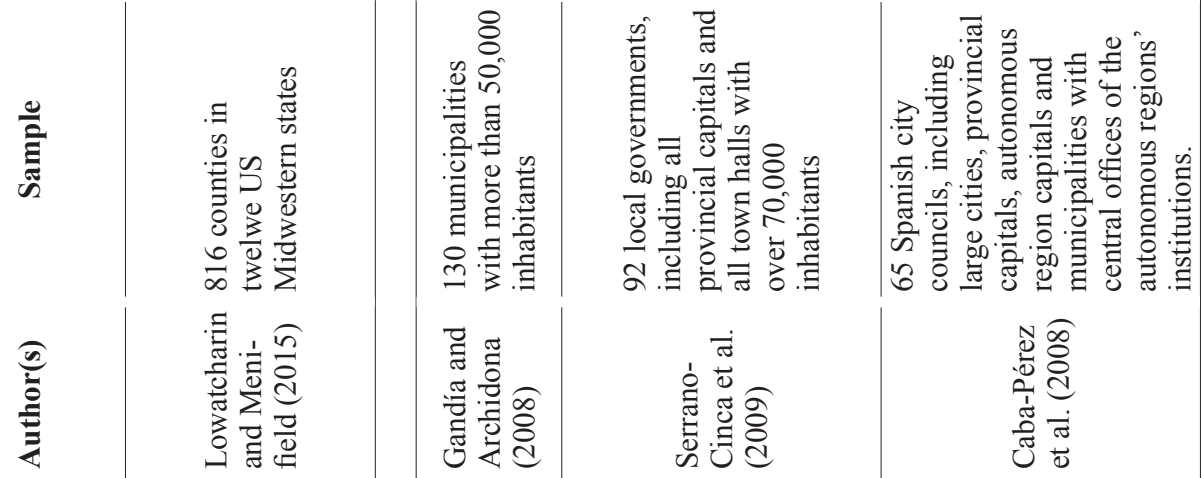
470
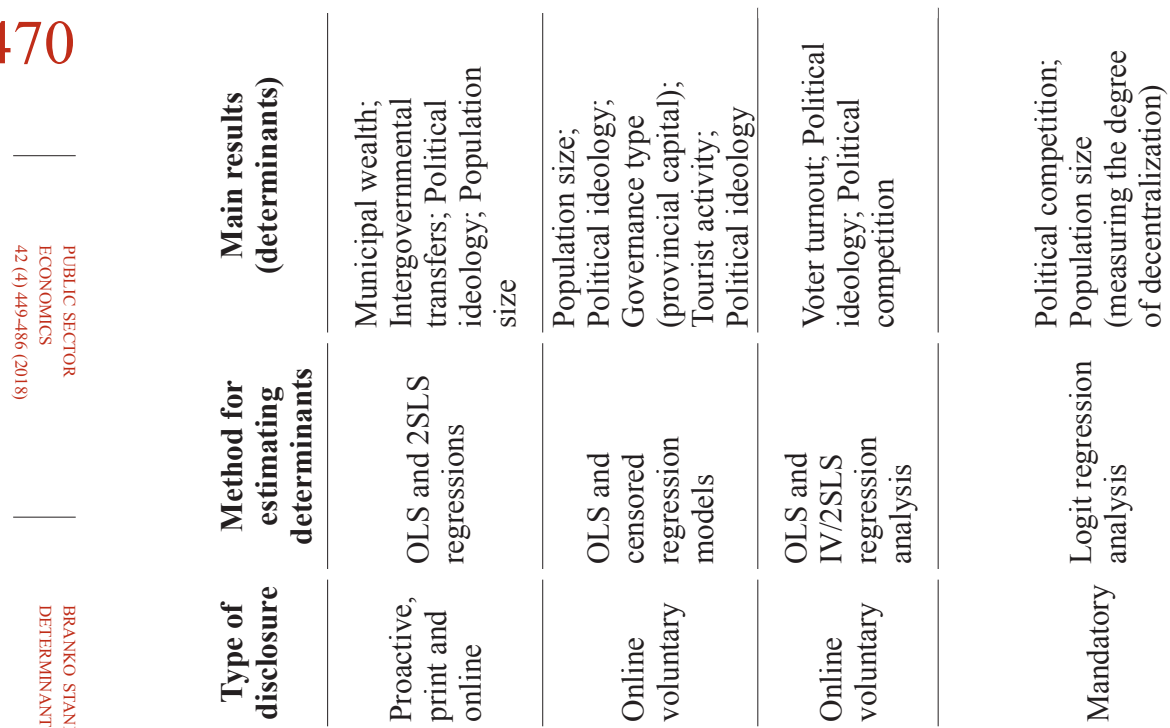

猆害
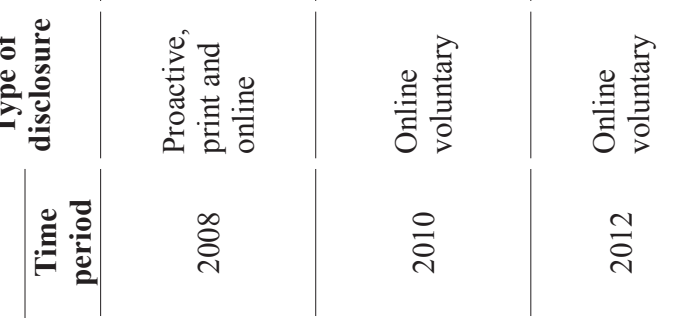

응
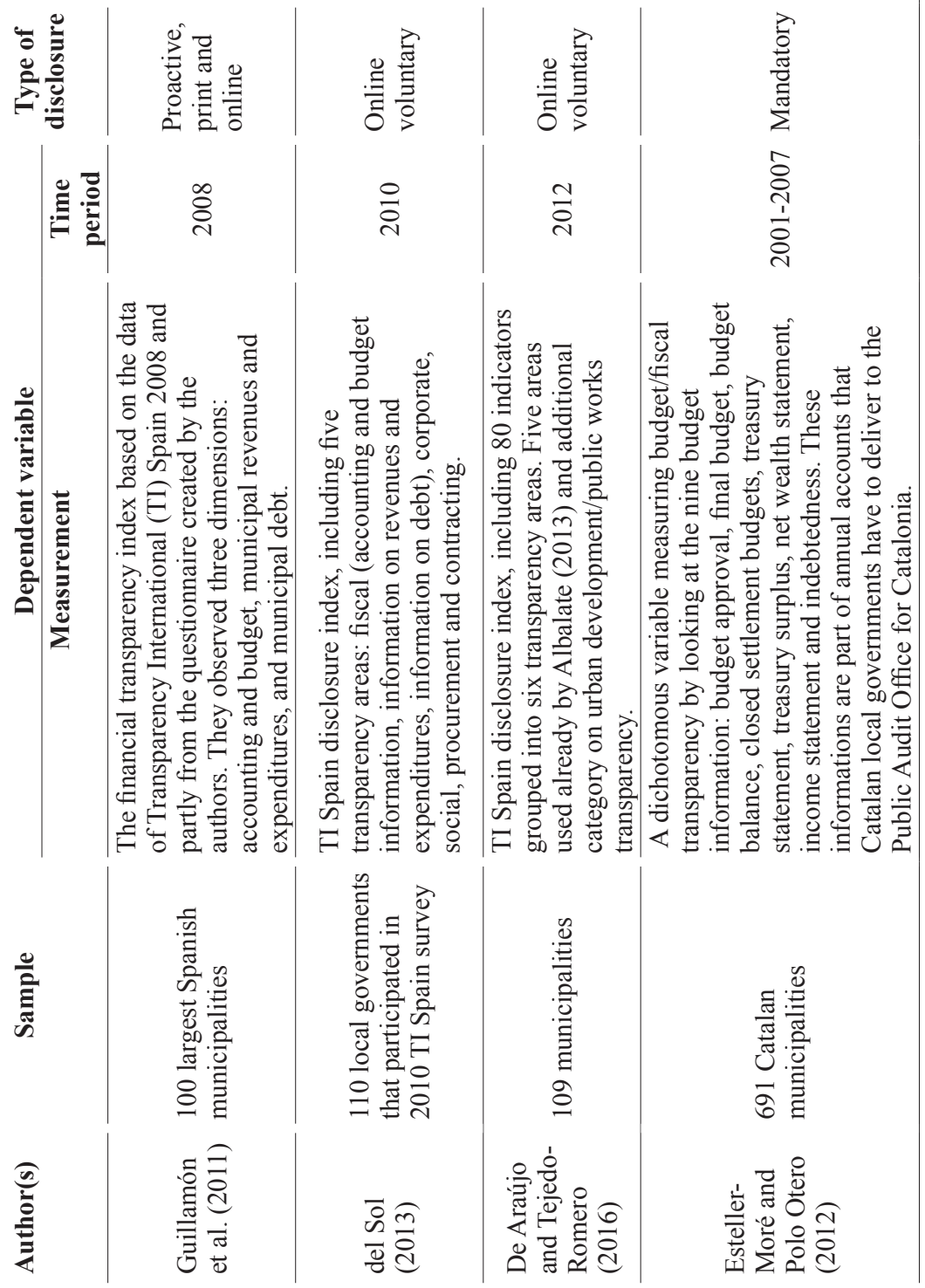


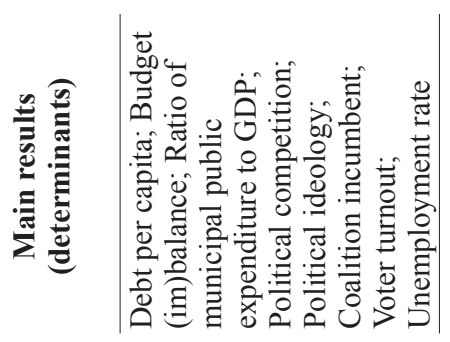

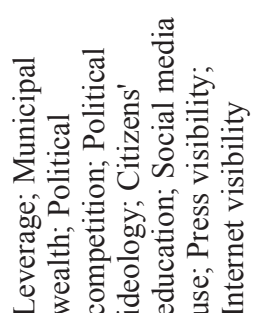

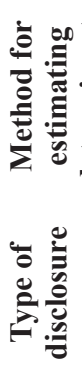
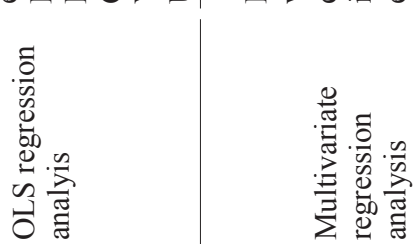

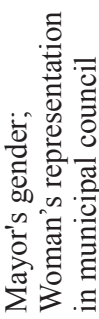

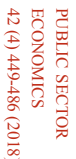
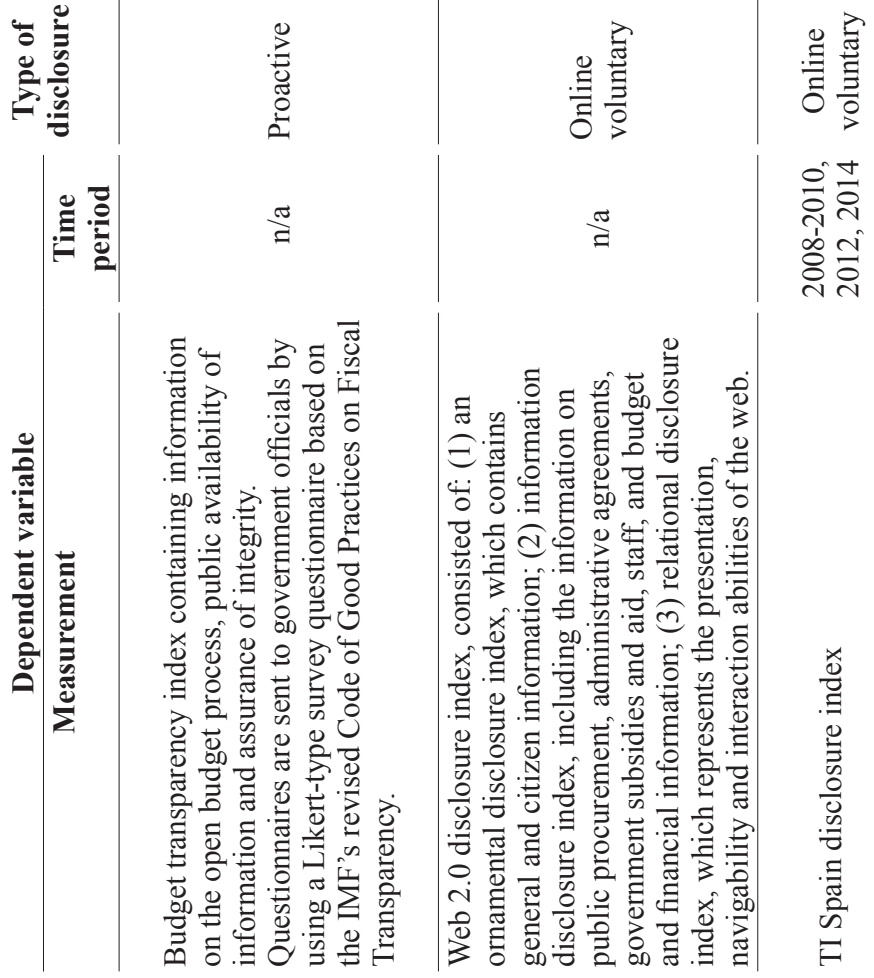

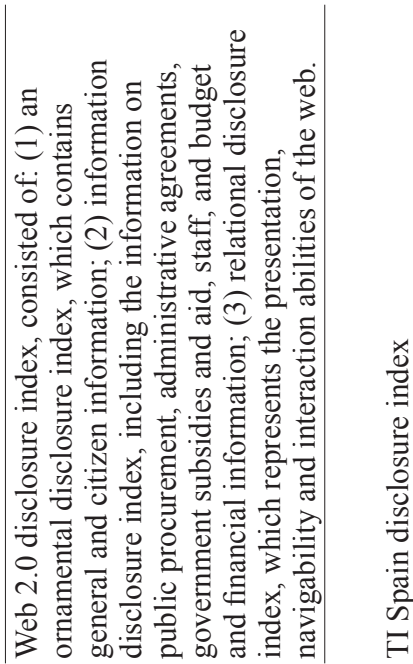

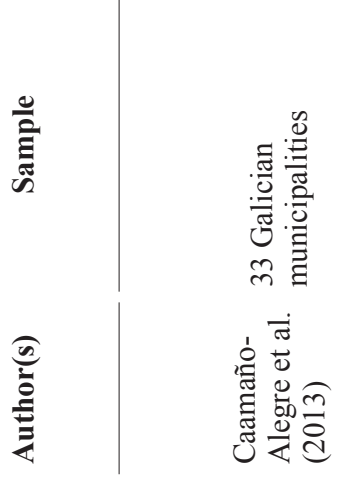

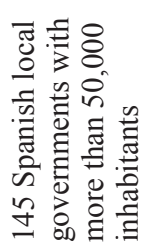

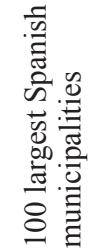

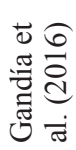

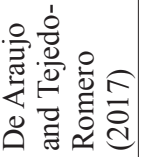




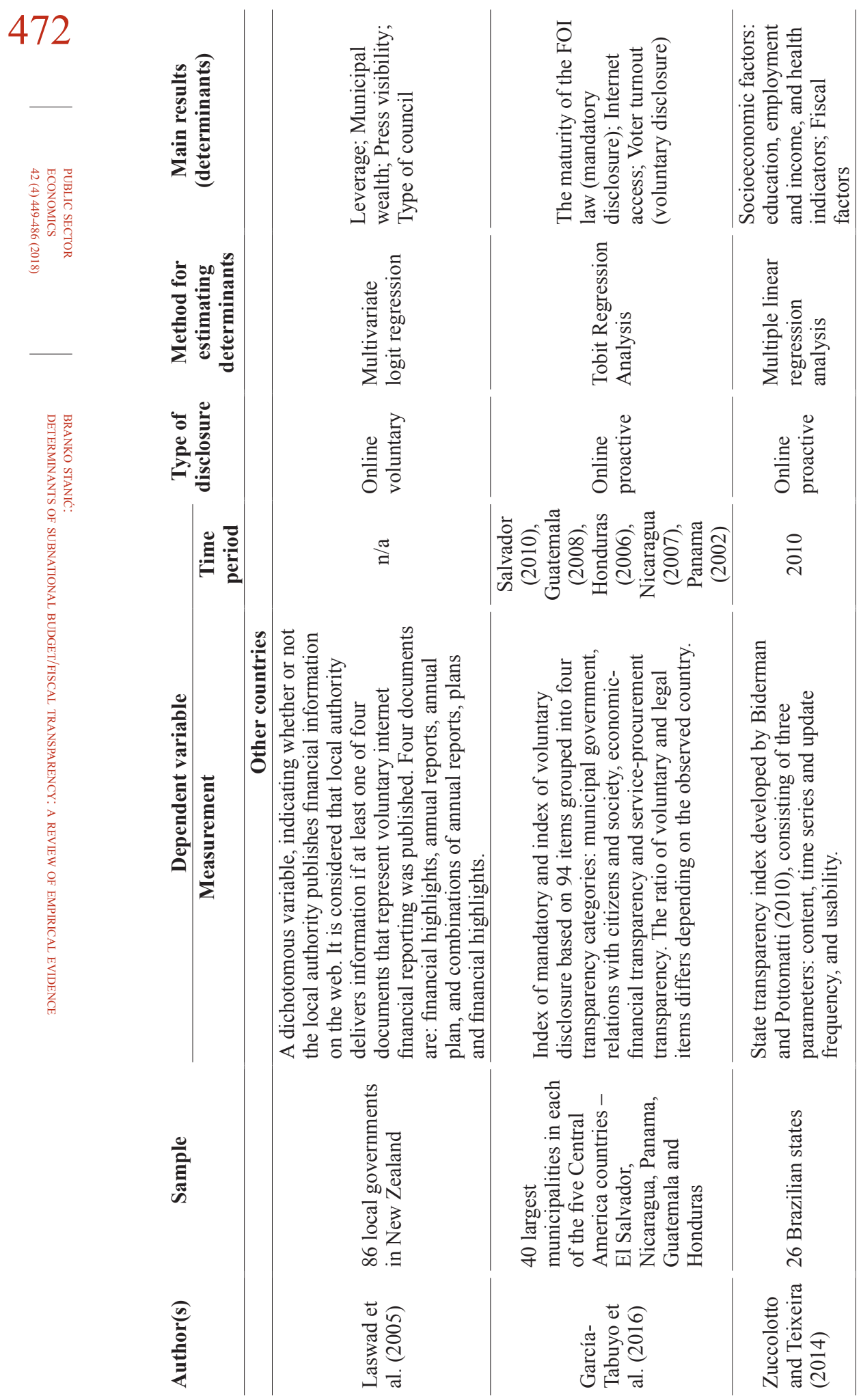




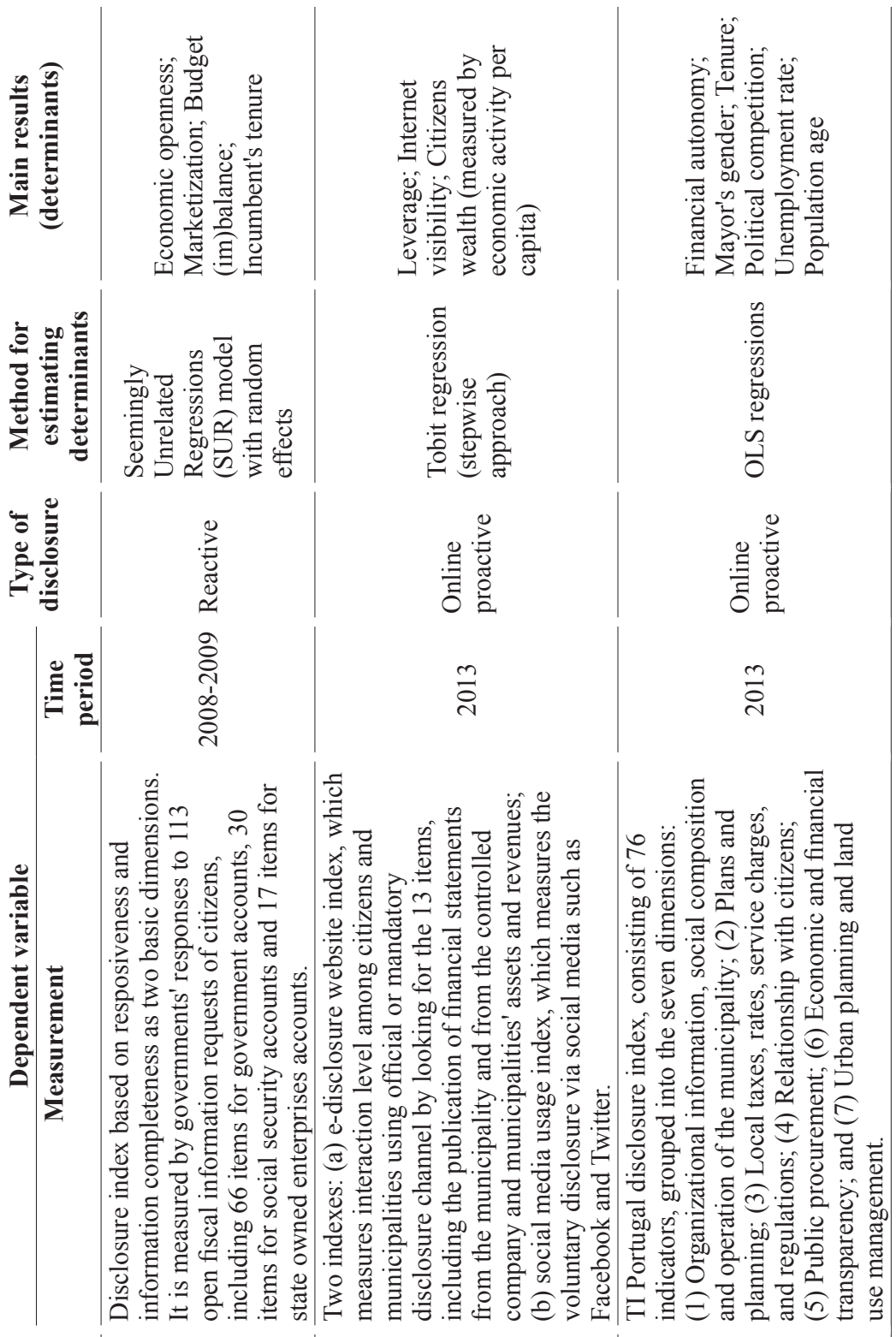




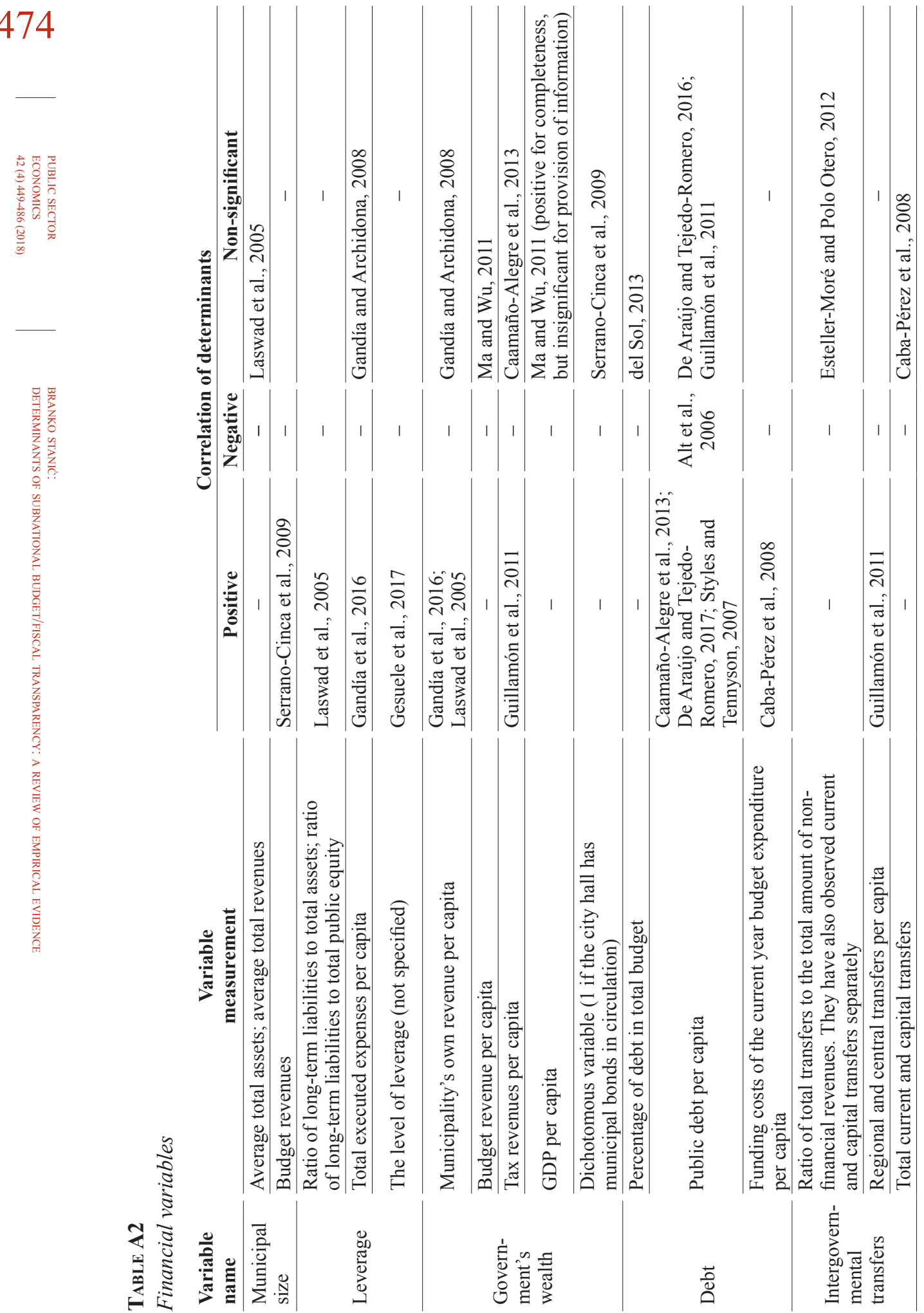



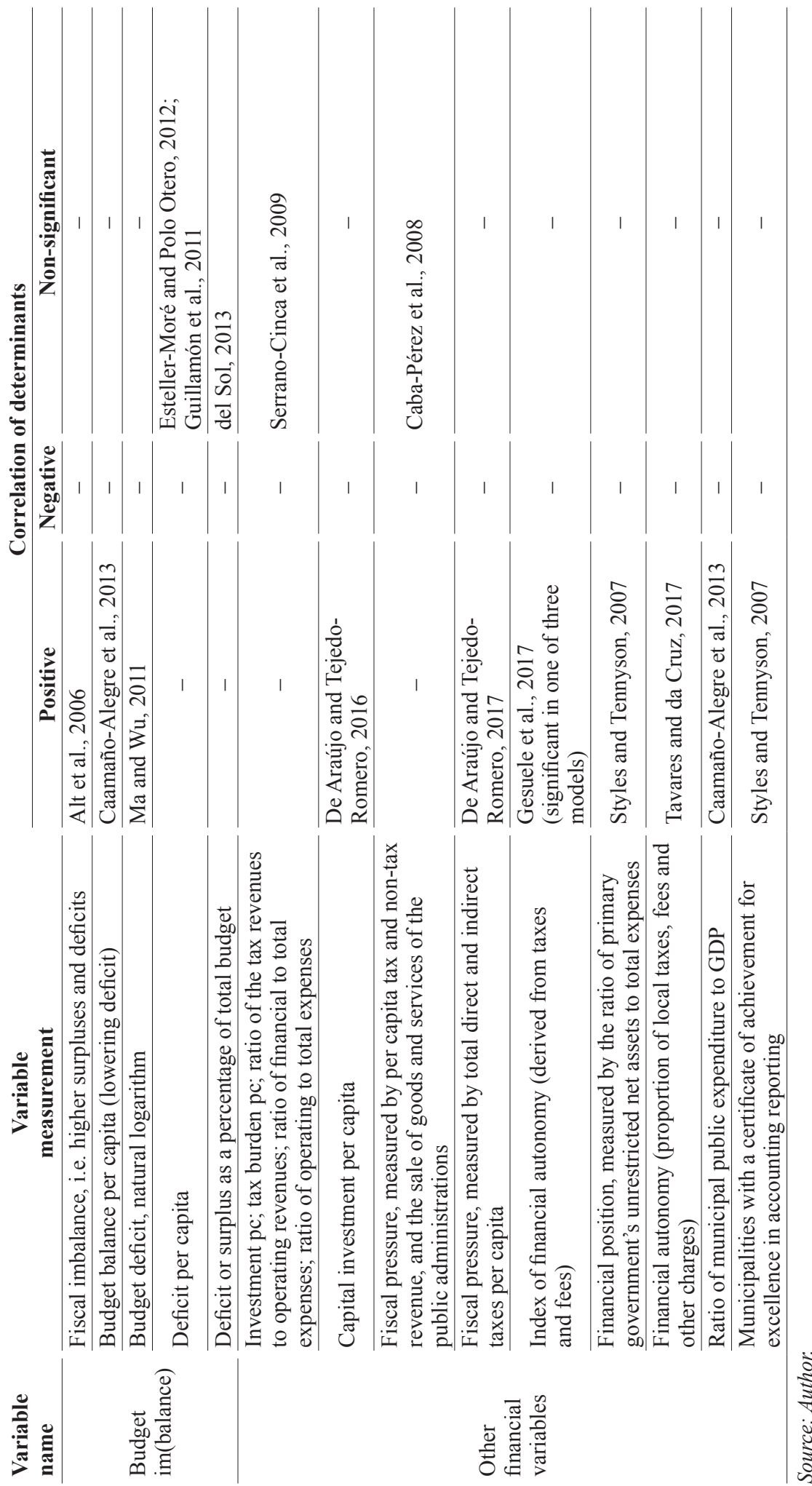


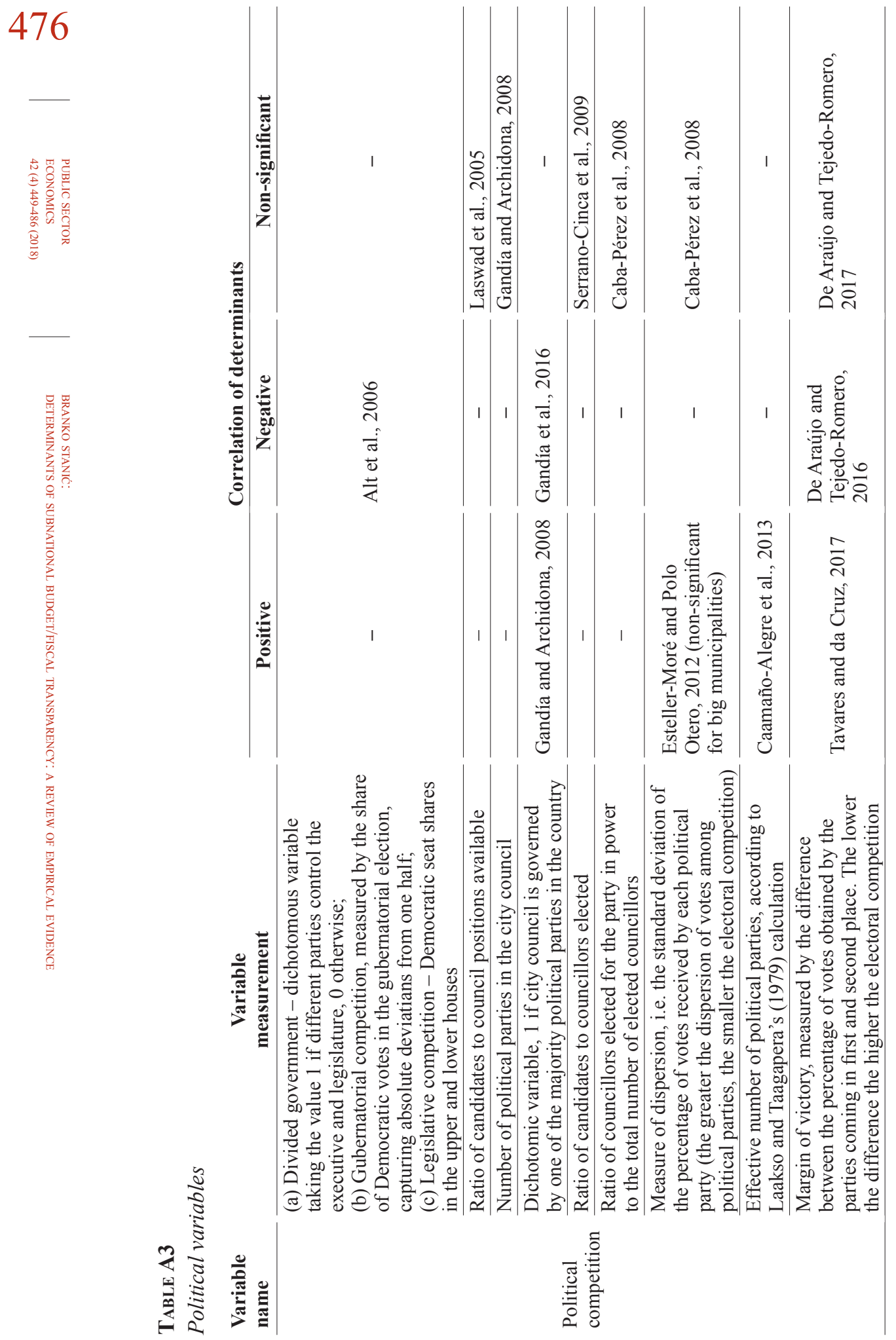



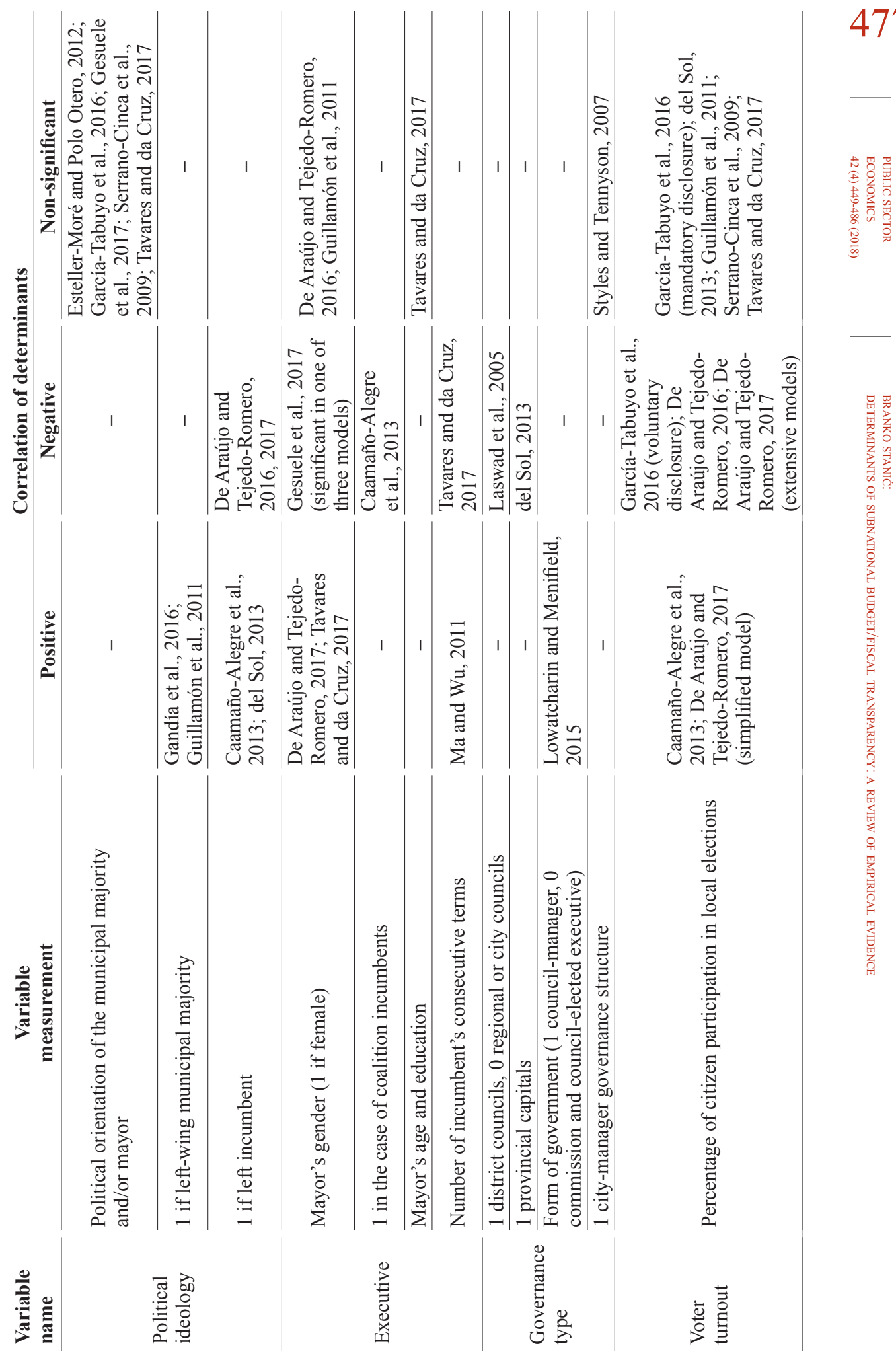
478
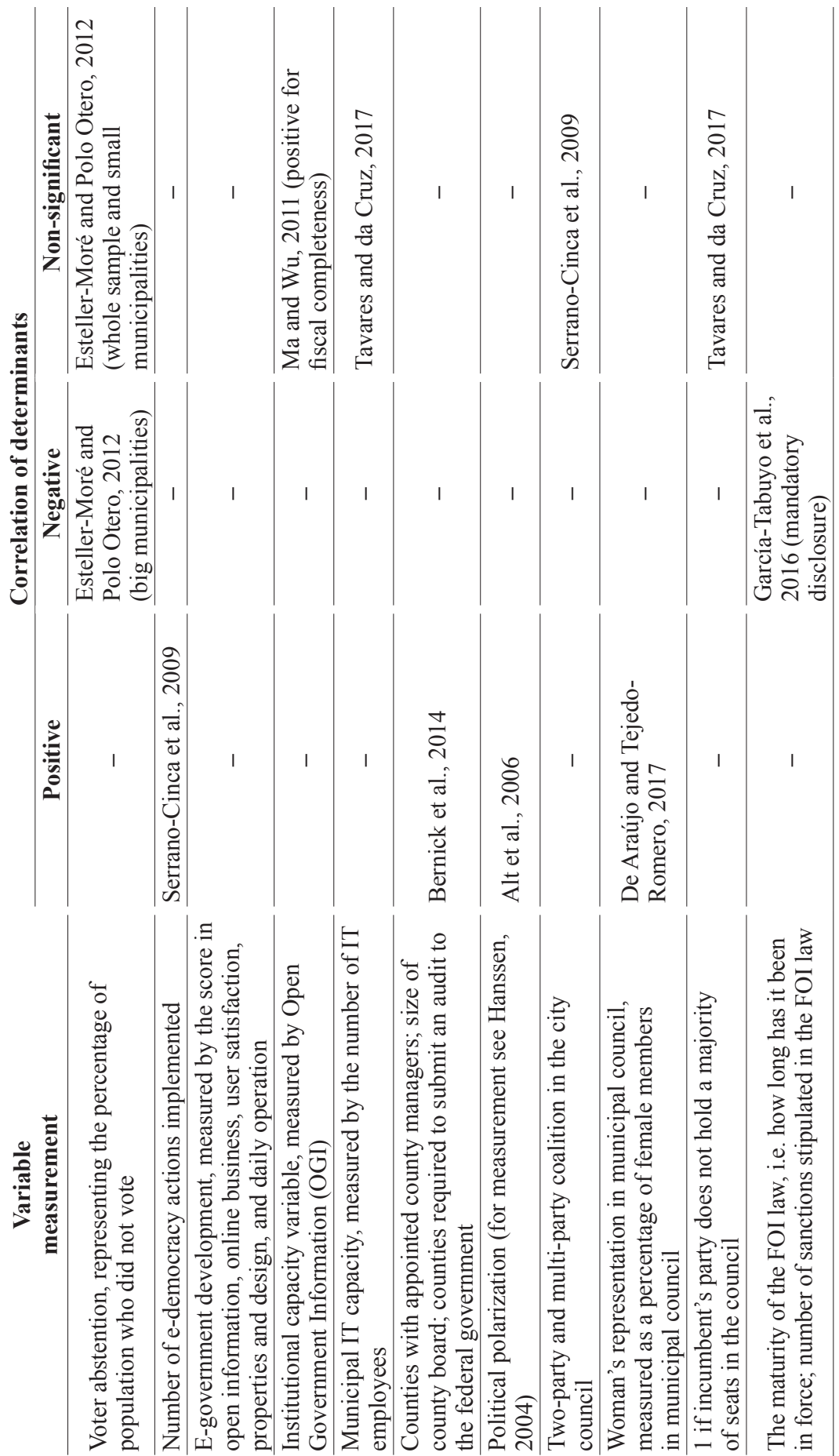

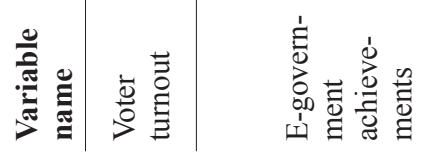

装量

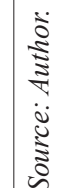




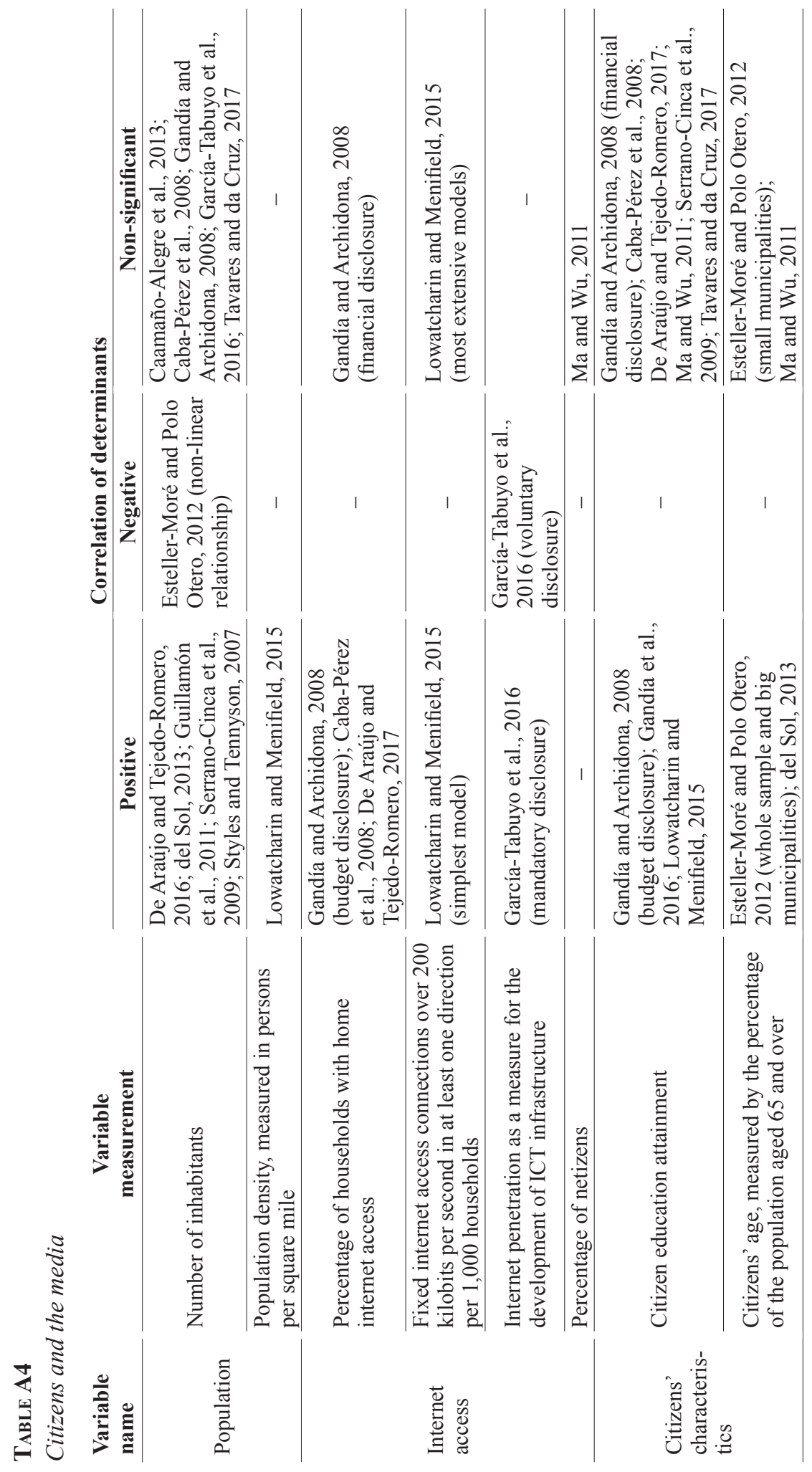




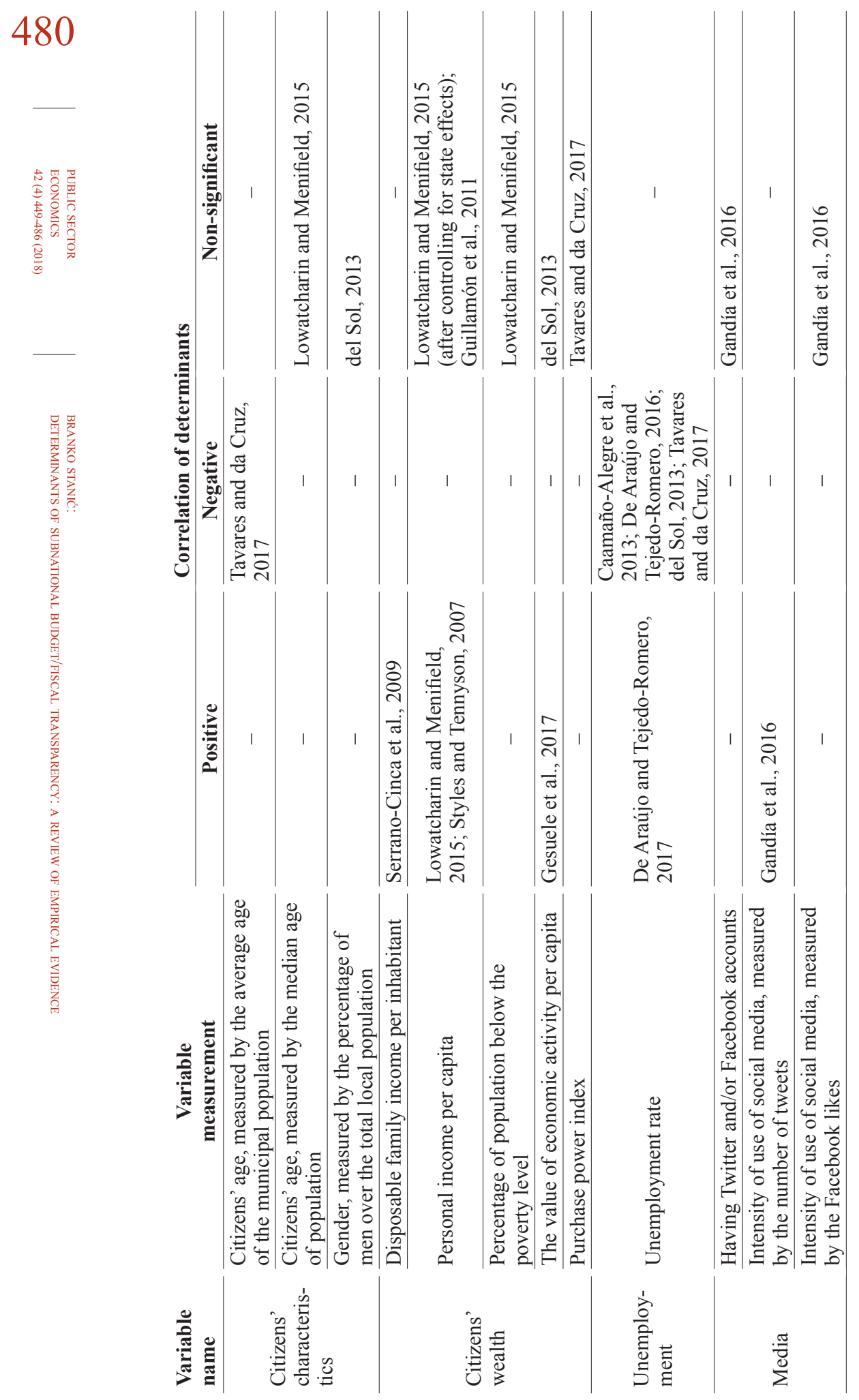




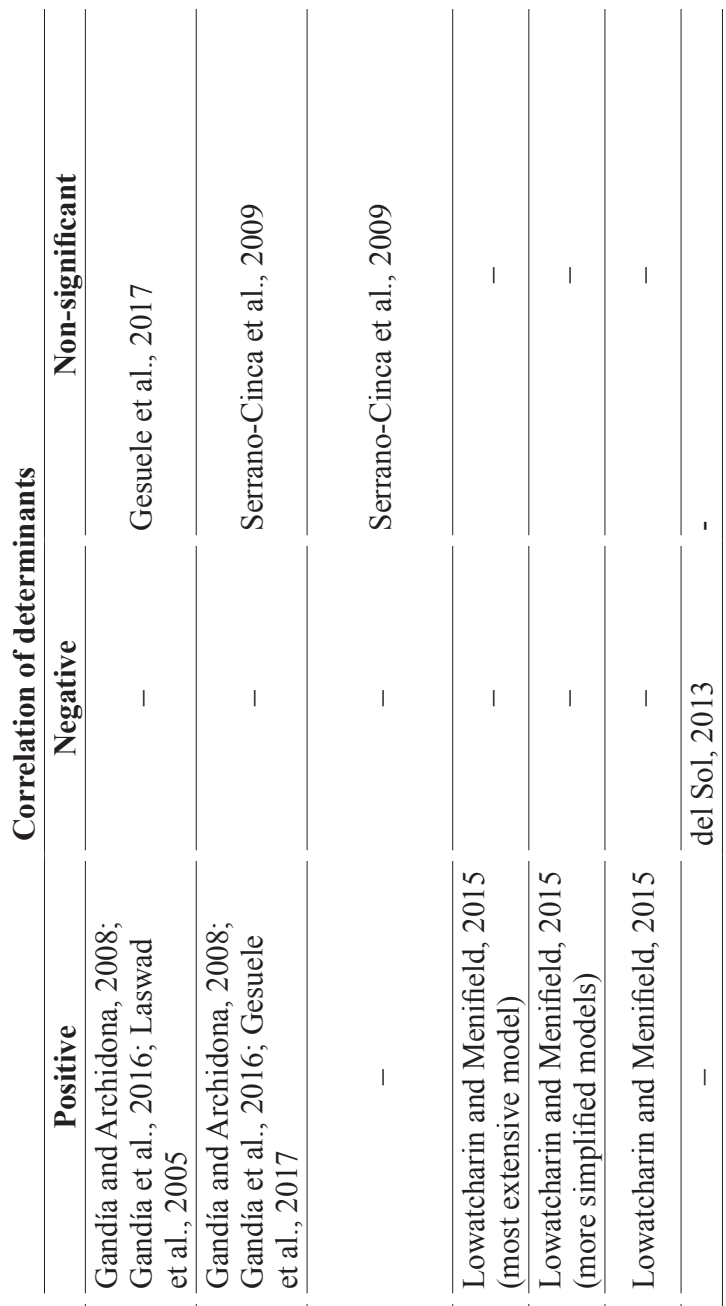

481
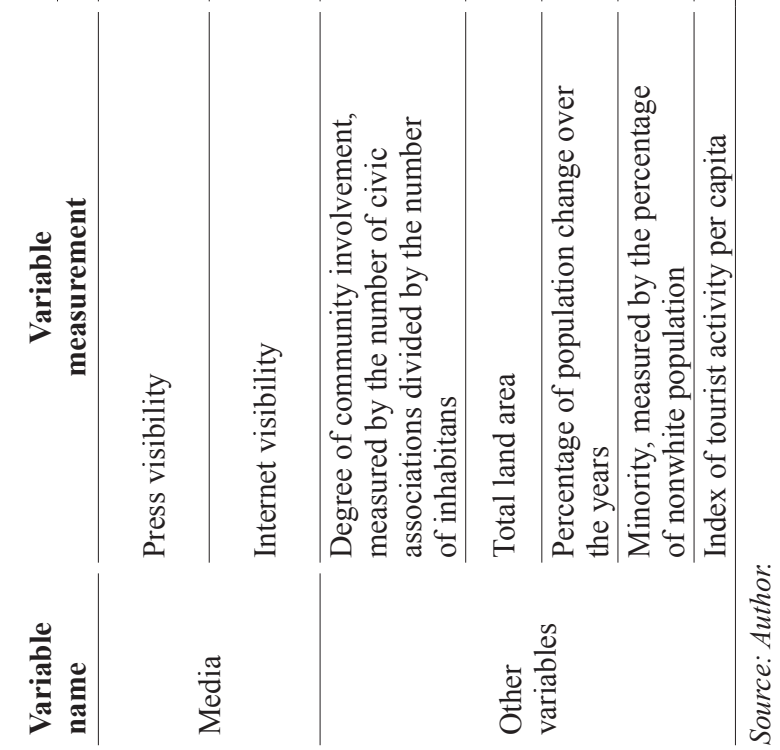


\section{REFERENCES}

1. Alt, J. E., Lassen, D. D. and Rose, S., 2006. The causes of fiscal transparency: evidence from the US states. IMF Staff Papers, 53(Spcial Issue). Available at: $<$ https://www.imf.org/External/Pubs/FT/staffp/2006/03/pdf/alt.pdf $>$.

2. Alt, J. E., Lassen, D. D. and Skilling, D., 2002. Fiscal Transparency, Gubernatorial Approval, and the Scale of Government: Evidence from the States. State Politics \& Policy Quarterly, 2(3), pp. 230-250. https://doi.org/10.1177/ 153244000200200302

3. Andreula, N., Chong, A. and Guillen, J. B., 2009. Institutional Quality and Fiscal Transparency. IDB Working Paper, No. 36. http://dx.doi.org/10.2139/ ssrn. 1817228

4. Bakar, N. B. A. and Saleh, Z., 2015. Review of literature on factors influencing public sector disclosure: The way forward. Asian Journal of Business and Accounting, 8(2), pp. 155-184.

5. Berliner, D., 2014. The political origins of transparency. Journal of Politics, 76(2), pp. 479-491. https://doi.org/10.1017/S0022381613001412

6. Berliner, D. and Erlich, A., 2015. Competing for Transparency: Political Competition and Institutional Reform in Mexican States. American Political ScienceReview, 109(1),pp.110-128.https://doi.org/10.1017/S0003055414000616

7. Bernardi, R. A. and Arnold, D. F., 1997. An Examination of Moral Development within Public Accounting by Gender, Staff Level, and Firm. Contemporary Accounting Research, 14(4), pp. 653-668. https://doi.org/10.1111/j.19113846.1997.tb00545.x

8. Bernick, E. L. [et al.], 2014. Explaining County Government Fiscal Transparency in an Age of e-Government. State and Local Government Review, 46(3), pp. 173-183. https://doi.org/10.1177/0160323X14556819

9. Biderman, C. and Pottomatti, G., 2010. Metodologia para construção de índice de transparência. Indice de transparencia. Available at: $<$ http://indicedetransparencia.com/metodologia/>.

10. Caamaño-Alegre, J. [et al.], 2013. Budget Transparency in Local Governments: An Empirical Analysis. Local Government Studies, 39(2), pp. 182-207. https://doi.org/10.1080/03003930.2012.693075

11. Caba-Pérez, C., Rodríguez Bolívar, M. P. and López Hernández, A. M., 2008. e-Government process and initiatives for online public financial information. Online Information Review, 32(3), pp. 379-400. https://doi.org/10.1108/JFM03-2013-0017

12. Caba Pérez, M. del C., Rodríguez Bolívar, M. P. and López Hernández, A. M., 2014. The determinants of government financial reports online. Transylvanian Review of Administrative Sciences, (42), pp. 5-31. Available at: $<\mathrm{http}$ ://www. rtsa.ro/tras/index.php/tras/article/download/15/13>.

13. Cuadrado-Ballesteros, B. [et al.], 2017. The Role of Media Pressure in Promoting Transparency of Local Governments. Transylvanian Review of Administrative Sciences, 2017(51E), pp. 20-37. https://doi.org/10.24193/tras.51E.2 
14. Darbishire, H., 2010. Proactive Transparency: The future of the right to information?. World Bank Institute Working Paper, No. 60. https://doi.org/ 10.1596/25031

15. De Araújo, J. F. F. E. and Tejedo-Romero, F., 2016. Local government transparency index: determinants of municipalities' rankings. International Journal of Public Sector Management, 29(4), pp. 327-347. http://dx.doi. org/10.1108/MRR-09-2015-0216

16. De Araújo, J. F. F. E. and Tejedo-Romero, F., 2017. Does Gender Equality Affect Municipal Transparency: The Case of Spain. Public Performance and Management Review, 41(1), pp. 69-99. https://doi.org/10.1080/15309576.201 7.1362350

17. Debreceny, R., Gray, G. L. and Rahman, A., 2002. The determinants of internet financial reporting. Journal of Accounting and Public Policy, 21(4-5), pp. 371-394. https://doi.org/10.1016/S0278-4254(02)00067-4

18. del Sol, D. A., 2013. The institutional, economic and social determinants of local government transparency. Journal of Economic Policy Reform, 16(1), pp. 90-107. https://doi.org/10.1080/17487870.2012.759422

19. Esteller-Moré, A. and Polo Otero, J., 2012. Fiscal Transparency: (Why) does your local government respond?. Public Management Review, 14(8), pp. 11531173. https://doi.org/10.1080/14719037.2012.657839

20. Evans, J. H. and Patton, J. M., 1987. Signaling and Monitoring in PublicSector Accounting. Journal of Accounting Research, 25, pp. 130-158. https:// doi.org/10.2307/2491083

21. Ferejohn, J., 1986. Incumbent performance and electoral control. Public Choice, 50, pp. 5-25. https://doi.org/10.1007/BF00124924

22. Fox, J., 2007. The uncertain relationship between transparency and accountability. Development in Practice, 17(4-5), pp. 663-671. https://doi.org/ 10.1080/09614520701469955

23. Fox, R. L. and Schuhmann, R. A., 1999. Gender and Local Government: A Comparison of Women and Men City Managers. Public Administration Review, 59(3), pp. 231-242. https://doi.org/10.2307/3109951

24. Gandía, J. L. and Archidona, M. C., 2008. Determinants of web site information by Spanish city councils. Online Information Review, 32(1), pp. 35-57. https://doi.org/10.1108/14684520810865976

25. Gandía, J. L., Marrahí, L. and Huguet, D., 2016. Digital transparency and Web 2.0 in Spanish city councils. Government Information Quarterly, 33(1), pp. 28-39. https://doi.org/10.1016/j.giq.2015.12.004

26. García-Tabuyo, M., Sáez-Martín, A. and Caba-Pérez, M. D. C., 2016. Mandatory versus voluntary disclosures: Drivers of proactive information provision by local governments in Central America. Information Development, 32(4), pp. 1199-1215. https://doi.org/10.1177/0266666915595260

27. García, A. C. and García-García, J., 2010. Determinants of Online Reporting of Accounting Information by Spanish Local Government Authorities. Local 
Government Studies. Routledge, 36(5), pp. 679-695. https://doi.org/10.1080/0 3003930.2010 .506980

28. Gesuele, B., Metallo, C. and Longobardi, S., 2017. The Determinants of E-Disclosure Attitude: Empirical Evidences from Italian and Spanish Municipalities. International Journal of Public Administration. Routledge, 20(4), pp. 263-276. https://doi.org/10.1080/01900692.2017.1300917

29. Gore, A. K., Sachs, K. and Trzcinka, C., 2004. Financial disclosure and bond insurance. Journal of Law and Economics, 47(1), pp. 275-306. https://doi.org/ $10.1086 / 380472$

30. Grimmelikhuijsen, S. G. and Welch, E. W., 2012. Developing and Testing a Theoretical Framework for Computer-Mediated Transparency of Local Governments. Public Administration Review, 78(1), pp. 562-571. https://doi.org/ $10.2307 / 41506806$

31. Groff, J. and Pitman, M., 2004. Municipal financial reporting on the World Wide Web: A survey of financial data displayed on the official websites of the 100 largest U.S. municipalities. Journal of Government Financial Management, 53(2), pp. 20-30.

32. Guillamón, M.-D., Bastida, F. and Benito, B., 2011. The Determinants of Local Government's Financial Transparency. Local Government Studies, 37(4), pp. 391-406. https://doi.org/10.1080/03003930.2011.588704

33. Hollyer, J. R., Rosendorff, B. and Vreeland, J. R., 2011. Democracy and transparency. Journal of Politics, 73(4), pp. 1191-1205. https://doi.org/10.1017/ S0022381611000880

34. IMF, 1997. World Economic Outlook. Washington: International Monetary Fund. Available at: <https://www.imf.org/external/pubs/ft/weo/weo1097/pdf/ octweo01.pdf>.

35. IMF, 1998. Code of Good Practices on Fiscal Transparency - Declaration on Principles. Washington: International Monetary Fund. Available at: <https:// www.imf.org/external/pubs/ft/history/2012/pdf/4d.pdf $>$.

36. IMF, 2012. Fiscal Transparency, Accountability, and Risk. Washington: International Monetary Fund. Available at: $<\mathrm{https}$ ://www.imf.org/external/np/pp/ eng/2012/080712.pdf>.

37. Ingram, R. W., 1984. Economic Incentives and the Choice of State Government Accounting Practices. Journal of Accounting Research, 22(1), pp. 126144. https://doi.org/10.2307/2490704

38. Khazanchi, D., 1995. Unethical behavior in information systems: The gender factor. Journal of Business Ethics, 14(9), pp. 741-749. https://doi.org/10.1007/ BF00872327

39. Kopits, G. and Craig, J., 1998. Transparency in government operations. IMF Occasional Papers, No. 158. Available at: <https://www.imf.org/external/ pubs/ft/op/158/op158.pdf>.

40. Krishnan, G. V. and Parsons, L. M., 2008. Getting to the bottom line: An exploration of gender and earnings quality. Journal of Business Ethics, 78(1-2), pp. 65-76. https://doi.org/10.1007/s10551-006-9314-z 
41. Laakso, M. and Taagepera, R., 1979. "Effective" number of parties: A Measure with Application to West Europe. Comparative Political Studies, 12(1), pp. 3-27. https://doi.org/10.1177/001041407901200101

42. Laswad, F., Fisher, R. and Oyelere, P., 2005. Determinants of voluntary Internet financial reporting by local government authorities. Journal of Accounting and Public Policy, 24(2), pp. 101-121. https://doi.org/10.1016/j.jaccpubpol. 2004.12.006

43. Lowatcharin, G. and Menifield, C. E., 2015. Determinants of Internet-enabled Transparency at the Local Level. State and Local Government Review, 47(2), pp. 102-115. https://doi.org/10.1177/0160323X15593384

44. Ma, L. and Wu, J., 2011. What Drives Fiscal Transparency? Evidence from Provincial Governments in China. $1^{\text {st }}$ Global Conference on Transparency Research, Rutgers University-Newark, May 19-20, 2011. https://doi.org/ 10.2139/ssrn.1807767

45. Michener, G., 2015. Why Policymakers Commit to Transparency: Legitimacy, Insurance, Monitoring and the Importance of the News Media as Mediator. Available at: <http://www.fiscaltransparency.net/resourcesfiles/files/2015070 2109.pdf>.

46. Moon, M. J. and Norris, D. F., 2005. Does managerial orientation matter? The adoption of reinventing government and e-government at the municipal level. Information Systems Journal, 15(1), pp. 43-60. https://doi.org/10.1111/j.13652575.2005.00185.x

47. Moon, M. J., 2002. The Evolution of E-Government among Municipalities: Rhetoric or Reality? Public Administration Review, 62(4), pp. 424-433. https://doi.org/10.1111/0033-3352.00196

48. Norris, D. F. and Kraemer, K. L., 1996. Mainframe and PC computing in American cities: Myths and realities. Public Administration Review, 56(6), pp. 568-576. https://doi.org/10.2307/977255

49. OECD, 2002. OECD Best Practices for Budget Transparency. OECD Journal on Budgeting, 1, pp. 7-14. https://doi.org/10.1787/budget-v1-art14-en

50. Pina, V., Torres, L. and Royo, S., 2010. Is E-Government Leading To More Accountable and Transparent Local Governments? an Overall View. Financial Accountability \& Management, 26(1), pp. 3-20. https://doi.org/ 10.1111/j.1468-0408.2009.00488.x

51. Piotrowski, S. J. and Bertelli, A., 2010. Measuring Municipal Transparency. $14^{\text {th }}$ IRSPM Conference, Bern, Switzerland.

52. Piotrowski, S. J. and Vanr Ryzin, G. G., 2007. Cittizens Attitudes Toward Transparency in Local Government. The American Review of Public Administration, 37(3), pp. 306-323. https://doi.org/10.1080/09638180126794

53. Rodríguez-Garcia, M. J., 2015. Local women's coalitions: Critical actors and substantive representation in Spanish municipalities. European Journal of Women's Studies, 22(2), pp. 223-240. https://doi.org/10.1177/ 1350506814549424 
54. Serrano-Cinca, C., Rueda-Tomás, M. and Portillo-Tarragona, P., 2009. Factors Influencing E-Disclosure in Local Public Administrations. Environment and Planning C: Government and Policy, 27(2), pp. 355-378. https://doi.org/ 10.1068/c07116r

55. Smith, A. C. and Taebel, D. A., 1985. Administrative innovation in municipal government. International Journal of Public Administration. Routledge, 7(2), pp. 149-177. https://doi.org/10.1080/01900698508524487

56. Styles, A. K. and Tennyson, M., 2007. The Accessibility of Financial Reporting of U.S. Municipalities on the Internet. Journal of Public Budgeting, Accounting \& Financial Management, 19(1), pp. 56-92.

57. Tavares, A. F. and da Cruz, N. F., 2017. Explaining the transparency of local government websites through a political market framework. Government Information Quarterly. https://doi.org/10.1016/j.giq.2017.08.005

58. Vishwanath, T. and Kaufmann, D., 1999. Towards transparency in finance and governance. Washington, DC: The World Bank.

59. Wehner, J. and de Renzio, P., 2013. Citizens, Legislators, and Executive Disclosure: The Political Determinants of Fiscal Transparency. World Development, 41(1), pp. 96-108. https://doi.org/10.1016/j.worlddev.2012.06.005

60. Zimmerman, J. L., 1977. The Municipal Accounting Maze: An Analysis of Political Incentives. Journal of Accounting Research, 15, pp. 107-144. http:// dx.doi.org/10.2307/2490636

61. Zuccolotto, R. and Teixeira, M. A. C., 2014. The Causes of Fiscal Transparency: Evidence in the Brazilian States. Revista Contabilidade \& Finanças, 25(66), pp. 242-254. https://doi.org/10.1590/1808-057x201410820 